INTERDISCIPLINARIA ARCHAEOLOGICA

\title{
Identifying Wheel-Thrown Vases in Middle Minoan Crete? Preliminary Analysis of Experimental Replicas of Plain Handleless Conical Cups from Protopalatial Phaistos
}

\author{
Ilaria Caloi ${ }^{1 *}$ \\ ${ }^{1}$ Department of Humanities, Ca' Foscari University of Venice, Dorsoduro 3484/D, 30123 Venice, Italy
}

\section{ARTICLE INFO}

\section{Article history:}

Received: $1^{\text {st }}$ February 2021

Accepted: $15^{\text {th }}$ November 2021

DOI: http://dx.doi.org/10.24916/iansa.2021.2.7

Key words:

Bronze Age Aegean

Minoan Crete

Experimental Archaeology

Ceramic-forming techniques

Potter's Wheel

\begin{abstract}
$A B S T R A C T$
Recent work in Middle Bronze Age Crete has revealed that most Protopalatial or First Palace period pottery is produced through the use of a combination of coil-building and the wheel, i.e., wheelcoiling. Experimental work conducted on pottery from Minoan sites of Northern and Eastern Crete (e.g., Knossos, Myrtos Pyrgos, Palaikastro) has indeed determined that Minoan potters did not develop the skills required to adopt the wheel-throwing technique. However, my recent technological study of Protopalatial ceramic material from Middle Minoan IIA (19 ${ }^{\text {th }}$ century BC) deposits from the First Palace at Phaistos, in Southern Crete, has revealed that though pottery was produced by the wheelcoiling techniques, yet other forming techniques were practised too.

In this paper I present a preliminary analysis of experimental replicas of MM IIA Phaistian plain handleless conical cups, manufactured on the potter's wheel using three different forming techniques: wheel-pinching, wheel-coiling, and throwing-off-the-hump. This analysis will proffer answers to several questions on the use of the potter's wheel in Middle Bronze Age Crete and opens the possibility that at MM IIA Phaistos there co-existed potters who had developed skills to employ different forming techniques on the wheel, including possibly that of throwing-off-the-hump.
\end{abstract}

\section{Introduction}

There is now a general agreement among scholars that the potter's wheel was developed on Crete around $1900 \mathrm{BC}$ (e.g., Evely, 1988; Knappett, 1999; Van de Moortel, 2006; Caloi, 2011), corresponding to the first emergence of palatial societies, but there is no agreement on the manner of use of this device across the island. Some scholars support the idea that the potter's wheel was used in combination with handbuilding, and especially coil-building, until the Late Bronze Age (Jeffra, 2013; Knappett, 2016); others state that wheelcoiling was not the only forming technique adopted on the island during the Middle Bronze Age, but that it co-existed with other forming techniques, including that of wheelthrowing (Speziale, 1999; MacGillivray, 1998; 2007; Van de Moortel, 2006; Berg, 2009; 2011; Wiener, 2011; Caloi, 2011; 2019; Todaro, 2017).

*Corresponding author. E-mail: icaloi@unive.it
One of the best approaches to assess the degree and manner of use of the potter's wheel is to examine the potential traces left by it on finished Minoan products, in comparison with those left on experimental reproductions under known conditions (Van der Leeuw, 1976; Rice, 1987; Courty, Roux, 1995; Outram, 2008; O'Sullivan et al., 2014). For this paper I used this approach, already applied at some scale to the Minoan evidence by Jeffra $(2011 ; 2013)$, to test the hypothesis that wheel-throwing was adopted in Protopalatial Crete, and especially at Phaistos, in Middle Minoan IIA (MM IIA). Unlike previous investigations, I chose to reproduce only a specific drinking pot - the plain handleless conical cup in use in Protopalatial times - but using three different techniques (wheel-pinching, wheel-coiling, and throwing-off-the-hump). To do so, I sourced raw materials (i.e., natural clays collected from Southern Crete) and tools (bronze and wood tools) that mirror those used in Minoan times, together with a potter's wheel reconstructed on the basis of the archaeological evidence provided by Minoan 
sites (Evely, Morrison, 2010) and a pit-kiln similar to the ones found at Pre- and Protopalatial Phaistos (see Todaro, 2016 for this "best practice approach").

The results point first to the existence of ceramic traditions that differ across the island and especially between Southern Crete and North/Eastern Crete, and second to the co-existence and co-working of potters employing different devices. It appears that at Middle Bronze Age Phaistos, individual potters or potting groups were operating, sharing only some stages of the manufacturing process, i.e., using the same clay sources and recipes of clay pastes, but practising different forming techniques. Alongside a variety of hand-building techniques, some combined with the use of the wheel, it is possible that also the wheel-throwing one was used to throw small pots, though this is little or not at all attested elsewhere on the island.

\subsection{Background: the ceramic technology of Protopalatial Crete $\left(19^{\text {th }}-18^{\text {th }}\right.$ century BC)}

The Middle Bronze Age in Crete includes the last phase of the Prepalatial period (i.e., MM IA), the whole Protopalatial period, which corresponds to the emergence of the First Palaces on Crete, and the first phase of the Neopalatial period (i.e., MM III) - cf. Table 1. I will mainly focus on the Protopalatial period, which is subdivided into three phases: MM IB, MM IIA and MM IIB (Table 1).

Table 1. Phasing of Middle Bronze Age on Crete with absolute dating.

\begin{tabular}{lll}
\hline Prepalatial period & MM IA & $2150-1900 \mathrm{BC}$ \\
Protopalatial period & MM IB & $1900-1850 \mathrm{BC}$ \\
& MM IIA & $1850-1800 \mathrm{BC}$ \\
& MM IIB & $1800-1700 \mathrm{BC}$ \\
Neopalatial period & MM III & $1700-1600 \mathrm{BC}$ \\
\hline
\end{tabular}

Most recent studies on the ceramic technology of Protopalatial pottery from sites of Northern and Eastern Crete (i.e., Knossos, Malia, Myrtos Pyrgos and Palaikastro - Figure 1) have revealed that after the introduction of the potter's wheel in MM IB ( $19^{\text {th }}$ century BC), the wheelcoiling method was the only forming technique employed in the island during the Protopalatial period and probably also later in the successive periods (Jeffra, 2013; Knappett, 2016; contra Berg, 2009; 2011). The four wheel-coiling methods identified by Roux and Courty (1998) in the prehistoric Levant have been recognised in the evidence provided by the Aegean world (Choleva, 2012). According to some studies on the Minoan evidence as supported by experimental works, the Minoans did not develop the skills to use the wheel-throwing technique, but preferred to use a combination between coilbuilding and the use of the wheel, i.e., wheel-coiling (Jeffra, 2011; 2013; Roux, Jeffra, 2015). At the time of the wheel's adoption on Crete, these studies tend to argue that there existed only one hand-building tradition, coil-building. But a number of studies have also shown that in Prepalatial Crete there existed other hand-building techniques, such as slab-construction, used to produce the well-known Early Minoan IIB Vasiliki Ware (Betancourt et al., 1979), pinching (Levi, Carinci, 1988; Van de Moortel, 2006), layering, and press-moulding (Todaro, 2019). According to Todaro (2017; 2019), most of these techniques went on to be used in combination with the potter's wheel in Protopalatial times.

Moreover, some scholars support the idea that in MM IIA the potter's wheel was used in its full potential to produce only small vessels, like the plain handleless conical cups. MacGillivray, first in 1998 (p.85) and again in 2007 (pp.130-132), suggested that at MM IIA Knossos a new class of cups appeared, produced in Fine Buff Crude Ware, which looks to be manufactured using the throwing-offthe-hump technique. Together with other scholars (Wiener, 2011, pp.356-357), he proposed that "this innovation was

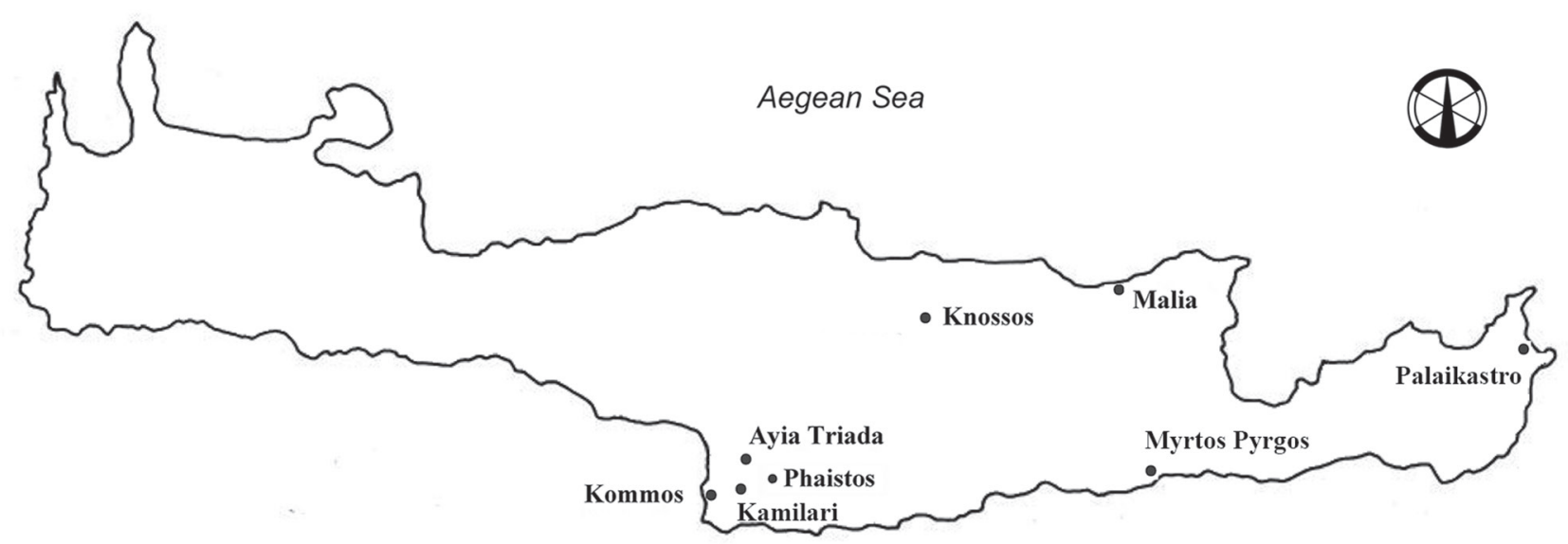

Lybian Sea

Figure 1. Map of Crete with an indication of Phaistos and other Minoan sites mentioned in the text. 
almost certainly borrowed from Egypt" (MacGillivray, 2007, p.131), where this technique, represented in a number of depictions, was introduced during the $\mathrm{V}^{\text {th }}$ Dynasty and then used to produce miniature vases (Doherty, 2015). At Protopalatial Knossos, some wheel-thrown handleless cups have been recognised by means of X-radiography by Berg (Berg, 2009; 2011; see also Knappett, 2004). In Southern Crete, recent studies conducted at the sites of Phaistos (Caloi, 2011; 2019; Todaro, 2017; Baldacci, 2017), Kommos (Van de Moortel, 2006, pp.328-329) and Ayia Triada (Baldacci, forthcoming) have also shown that wheel-coiling was not the only technique in use in the Protopalatial period.

In Minoan Crete, only ceramic discs have been recorded in the archaeological record (Xanthoudides, 1927; Hampe, Winter, 1962; Evely, 1988; Puglisi, 2018), while no actual complete "Minoan wheels" have been preserved and no representations of these instruments are available in the Minoan media. For this reason, scholars have tried to reconstruct the potter's wheel used in Minoan times on the sole basis of the archaeological evidence recorded at the sites (Evely, 1988; Morrison, Park, 2008; Evely, Morrison,
2010) and through ethnographic parallels. In particular, experimental archaeology using the potter's wheel reconstructed by Morrison with Park (2008) showed that this device can produce enough rotational kinetic energy (RKE) not only to finish/shape vases, but also to throw vessels of small dimensions. It is also relevant to mention that experimental archaeology conducted using ancient Egyptian wheels (defined as "high velocity, low inertia") indicated that the latter could be used to throw only lumps of clays not heavier than 1-2 kg (Powell, 1995, p.394).

\section{Methods}

For this work, I pursued a combined approach. This integrates the macroscopic examination of locally-made, plain handleless cups and a detailed study of the traces identified on these same vessels with the testing of their technological properties by experimental reproduction carried out by a professional potter, Vassilis Politakis (http:// www.spiritofgreece.gr/).
Figure 2. The schematic development of the Phaistos handleless conical cups from Early Minoan III to Late Minoan III with an indication of the MM IIA experimental cup forms (in the oblong) - with its three variations - used for this experimental work (after Fiandra, 1973, Plate 21).
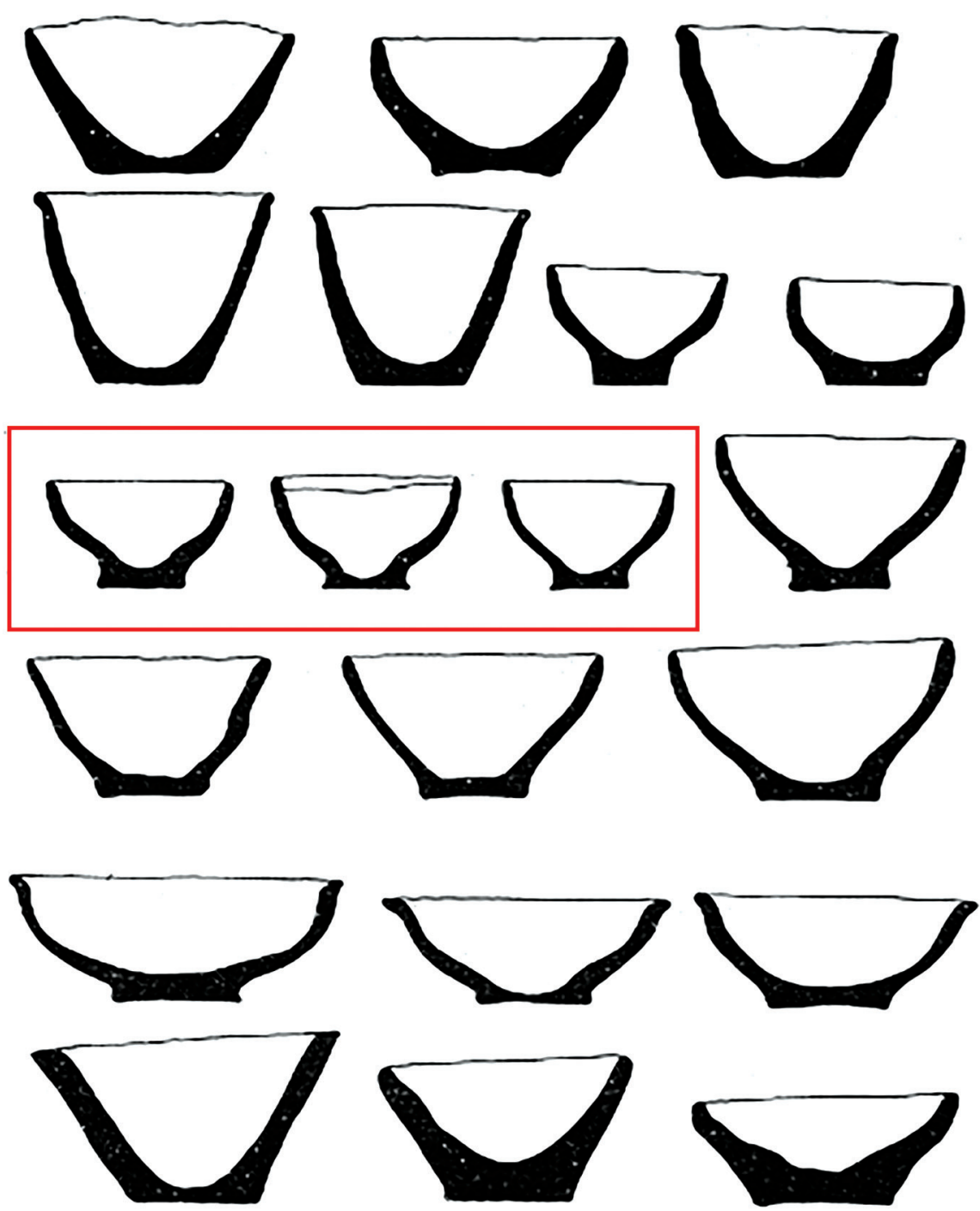


\subsection{The experimental profile: the plain handleless conical cup}

As mentioned, for this paper I focus on one local product of Protopalatial Phaistos, the MM IIA plain handleless conical cup produced in fine buff fabric. There are three reasons for this choice. First of all, this common drinking cup is a typical shape of Phaistos (Fiandra, 1973, pp.86-88, Plate 21), well attested in the palatial centre from the end of the Early Bronze Age until the Late Bronze Age (Figure 2). It is also present in the nearby sites sharing the ceramic tradition of Phaistos (e.g., Haghia Triada, Kommos) and in a few sites of Southern Crete, especially the Mesara tholos tomb cemeteries (e.g., Kamilari and Koumasa), but absent or rarely attested in the rest of the island at least until MM III (Levi, Carinci, 1988; Wiener, 2011). Hitherto, Knossos is the only site from Northern Crete that has revealed deposits of MM IIA and MM IIB containing this kind of cup (MacGillivray, 2007, pp.130-132; Macdonald, Knappett, 2007, pp.113-115). Second, the large number of MM IIA handleless conical cups retrieved from structured deposits within the palace seem to testify to the use of different techniques to produce them (Caloi, 2012; 2016). Finally, these cups were manufactured without being given a perfect finish: the absence of any secondary treatment of the vase surface allows for an easier identification of traces left by the primary forming technique.

The pottery samples analysed in this study originated from two MM IIA homogeneous deposits retrieved from the main palatial edifice of the First Palace at Phaistos - the South-West building - during the Doro Levi's excavations conducted from 1950 to 1966 (Levi, 1976) under the aegis of the Italian Archaeological School at Athens. They come respectively from Room IL and the Bastione II wall of the palatial South-West building (Caloi, 2012; 2016). The first included 430 plain handleless conical cups, the second 300 examples.

The profile chosen for the experiment is the MM IIA one, as presented by Fiandra (1973) in Plate 21, here illustrated in Figure 2. This form, which ranges from a bell-shaped to a strict conical profile, shows a pronounced hollow within the base interior. The ceramic material used for the manufacture of handleless conical cups of MM IIA is very fine, with no inclusions. This is one of the main differences with the handleless conical cups of the previous period, i.e., MM IB (Caloi, 2009).

A variety of diagnostic attributes have been used for the identification of pottery-forming techniques by a number of scholars, like variability in topography of walls, type of fractures, surface morphology, specific breakage (Rice, 1987; Courty, Roux, 1995; Choleva, 2012; Jeffra, 2011; Roux, 2019). These attributes, however, are not always preserved in the ceramic material and can be "polysemic", as defined by Courty and Roux (1995, p.18). This means that they may be produced both by wheel-fashioning and wheelthrowing (see also Rice, 1987).

With these limits in mind, I decided to focus not only on single features, but on clusters that could be attributed to a specific forming technique. Future study will also include the study of microscopic traces to understand whether the orientation of pores and clay domains may help in distinguishing the use of different forming techniques.

\subsection{Experimental archaeology}

Experimental archaeology was carried out in collaboration with the professional potter Politakis, who reproduced 50 examples of MM IIA-style vases from Phaistos. Because of the 2020 restrictions due to the Covid emergency, I was not able to go to Crete and proceed with my project in person there. For this reason, I could only manage to employ one potter to produce replicas and I myself fashioned a limited number. With these restrictive circumstances in mind, in this paper I am going to present only the 50 experimental plain handleless cups he produced using the three following forming techniques: 1) pinching and then final shaping on the wheel, i.e., wheel-pinching; 2) coiling and shaping on the wheel, i.e., wheel-coiling; and 3) throwing-off-the-hump.

\subsubsection{The kit-tool for experiments}

Before describing the three forming techniques adopted, it is important to note that the experimental work was undertaken using materials and tools which mirror as much as possible those in use in Minoan times, as sourced in the archaeological evidence from palatial Crete.

I used natural clays collected from Southern Crete, and especially from Moni Odiyitria and Vori; these clay sources are compatible with those used in Prepalatial and Protopalatial times to produce the well-known Mesara fine decorated pottery, and especially the EM IIA Fine Painted Ware and the MM IB-IIB Kamares Ware (Day, Relaki, Faber, 2006; Mentesana et al., 2016). Two different clays were used: the first one was grey and the second, which was red, was a colluvial terra rossa (Mentesana et al., 2016, pp.305-306). We mixed these two different clays using only water and did not add other tempering. This last was done because most of conical cups from MM IIA deposits are produced in a very fine and pure fabric, which does not show inclusions, except for the natural inclusions of the clay. Both the clays showed good plasticity.

For my experimental reproductions, I adopted a replica of a Minoan potter's wheel constructed by Politakis on the basis of the model proposed by scholars for the palatial period on Crete, and especially by Evely (1988, Figure 10; 2000, p.270) and Morrison (Evely, Morrison, 2010; Morrison, Park, 2008). In his workshop at Heraklion, Politakis constructed the experimental wheel with a cross-bar (Figure 3). It is set on the floor, not in a pit. It was composed of a ceramic wheelhead (see Caloi, 2019, Figure 4c) that replicates the ones found at Protopalatial Malia in Eastern Crete (Poursat, Knappett, 2005, p.34; Evely, 1988, pp.90-91) with a central scored socket on its lower side (Figure 3). The ceramic disc was fixed to the ceramic supporting collar and the wooden (oak wood) vertical axle, using hydrated clay. Then, as a whole, the wheel was threaded through a hole in the crossbeam support and into a heavy pivot stone sitting on the floor (Figure 3). 
Figure 3. The potter's wheel reconstructed by V. Politakis, broadly following the reconstructions proposed by D. Evely and J. Morrison. Photograph by author.

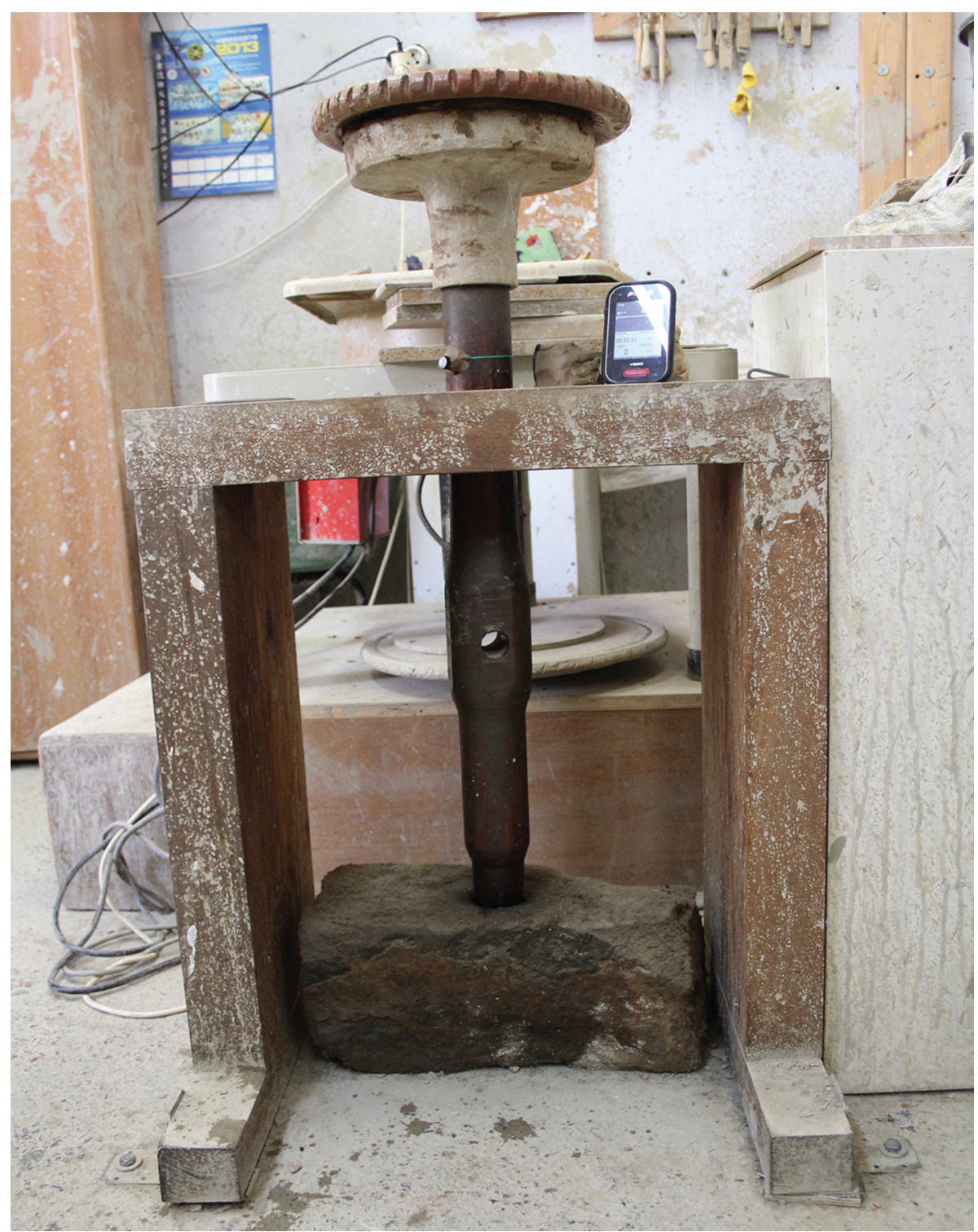

Within the framework of my own experiment with this potter's wheel, I decided to have the wheel operated by an assistant who rotated the axle, leaving the potter to work seated and with both hands free. The help of an assistant allowed the wheel to maintain its rotary speed at a maximum and to generate enough momentum to permit throwing/ fashioning on the wheel. The potter's wheel functioned well only when the assistant could help rotate the axle in a constant way. We do not have any sources for Minoan Crete concerning the presence of an assistant, but ethnographic parallels in modern Crete helped in suggesting that a second person was present (Evely, 1988). Using a speed calculator (visible in Figure 3), we tried to keep up a speed constant between $85-100 \mathrm{rpm}$.

The tools used to trim rims and to apply water to the experimental vases on the wheel were respectively a bronze tool and a natural sponge, while the strand used to cut off the vases from the wheel surface was made from six hairs of a donkey.

The vases were fired at 720-800 degrees C in a pit-kiln (Caloi, 2019, Figure 5), reconstructed by Politakis following the Minoan pit-kilns, especially the Prepalatial and Protopalatial ones found in the Potters' Quarter of Phaistos (e.g., Todaro, 2009, p.337, Figure 2).

\subsubsection{The experimental reproduction of three forming techniques}

The first technique we attempted was the wheel-pinching, that is the formation first of a handleless cup from a small clay ball (i.e., by pinching it up) and then the final shaping of this cup on the wheel (Figure 4a). For this experiment, we followed the general outline for the pinching technique (Rice, 1987, pp.125-126). We first made our clay into a lump, then fashioned a hole by pressing a thumb down into its centre, while supporting the outside with the fingers. Then, the walls were progressively thinned by pressing and squeezing the clay between the thumb and the fingers. When the roughout was ready (Figure 4a), we put it on the wheel in order to thin the walls and shape the final form. We created 15 replicas.

The second technique involved the coil-building of a cup and its final shaping on the wheel, i.e., wheel-coiling 


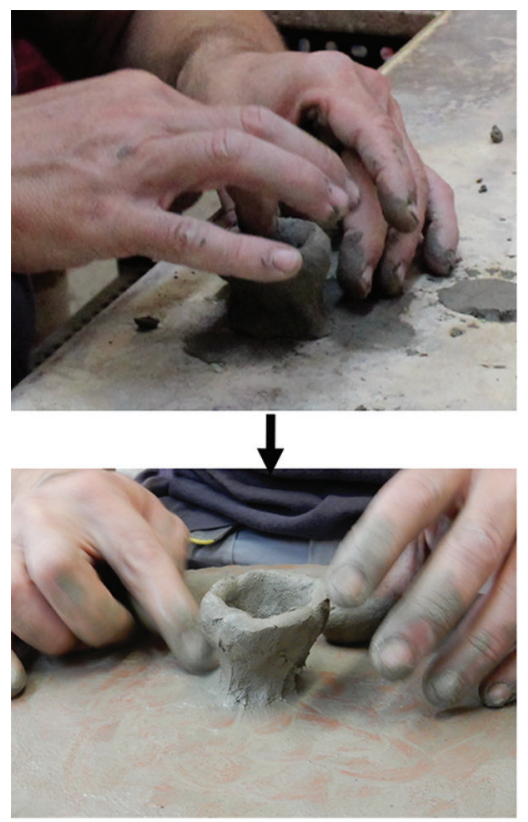

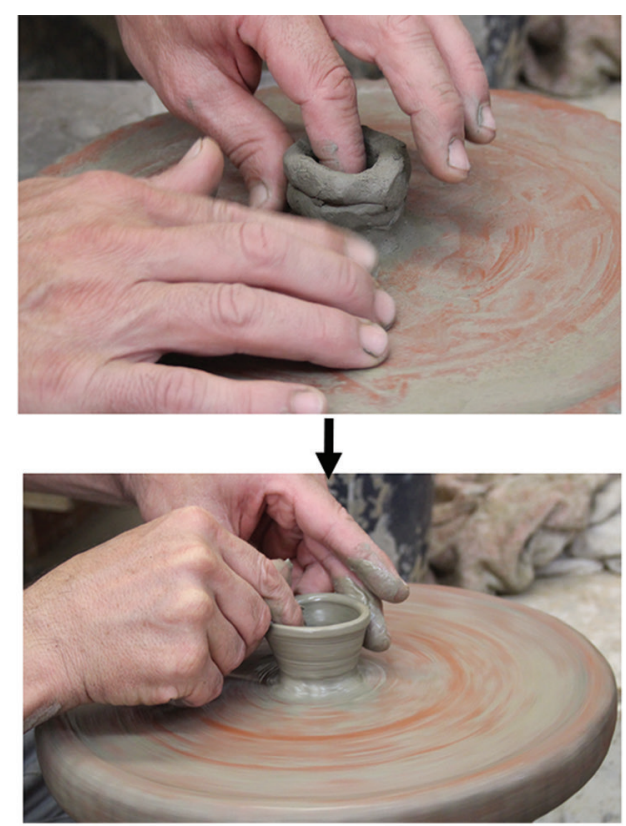

b

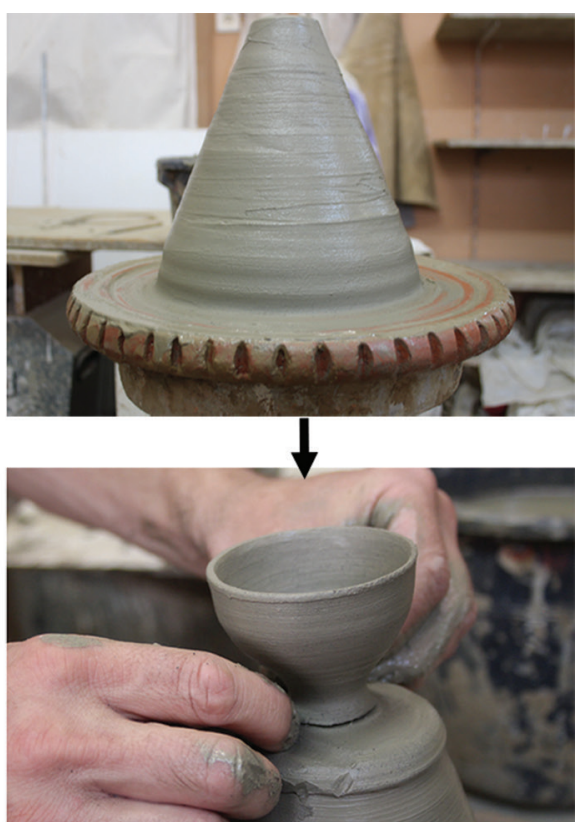

c

Figure 4. The three forming techniques used by the potter V. Politakis to reproduce MM IIA handleless conical cups from Phaistos: a) pinching and final shaping on the wheel; b) wheel-coiling; c) throwing-off-the-hump. Photographs by author.

(Figure 4b). We used three coils with circular sections of $1 \mathrm{~cm}$ thickness, set on a circular base $1 \mathrm{~cm}$ thick and $3 \mathrm{~cm}$ across. The joints between the coils were oriented to the interior, to match the traces of coils left on the analysed archaeological material from MM IIA deposits of Phaistos (see Figure 16). Once the coils were positioned, the wheel was exploited for joining the coils, thinning the walls and shaping the roughout (Figure 4b). Once the roughout was achieved, the pot was finally shaped in both its upper and lower parts on the wheel. The surfaces were left as they were, without smoothing them. This technique corresponds to the above-mentioned wheel-coiling Method 3, first defined by Roux and Courty (1998) for the Southern Levant, and then recognised by Jeffra $(2011 ; 2013)$ and Choleva (2012) in Aegean ceramics. We created 10 replicas.

The third technique was throwing-off-the-hump (Figure 4c): so fashioning cups or small vases from the clay at the top of a large lump, also called a mound. Placing the mound on the wheel as one piece, it was centred, starting from the top. The clay was pressed down against the wheel head as it was centred. The second step was opening up the very top of the mound and pulling the clay up to make the cup. Finally, the cup was cut off of the hump with the strands of hair (Figure 4c). We also tried to cut the vase off the hump using a bronze needle.

We created 25 replicas.

\subsubsection{Analysis of the replicas: trace description and comparative study}

The analysis of replicas has shown that there are some features that seem to be attributable to a specific forming technique, whereas there are others that seem random and cannot be accepted as clear evidence of a specific forming technique, like the thinning of the rim or the striations on the base exterior. Most of them have been already discussed by Courty and Roux (1995), Jeffra (2011), Choleva (2012), and Roux (2019, pp.178-180).

In a number of cases, replicas show specific features or clusters of features that are attributable to a single forming technique, as indicated by the macroscopic traces left on the vase. For this particular experiment, for example, strong finger imprints on the outer face, especially on the lower part of the vase (Figures 5 and 6) when associated with rilling on the upper part (inside and/or outside) are features identified only on wheel-pinched vases. The outer face may also show crevices in association with the hollows left by the finger imprints (Figure 6). The inner face frequently presents a smooth, fluidified surface or may show fingerprints and/or short lines near the rim left by the potter's finger (Figure 6).

There are some features that seem attested only on wheel-coiled vases, like short fissures, which appear more frequently on the inner face, but also on the outer face (Figure 7), and are often associated with compression folds (Figure 7). These fissures can be horizontal or curvilinear, as described by Jeffra for replicas of Protopalatial cups from North/North Eastern Crete (Jeffra, 2011). On some wheelcoiled replicas, there remain only horizontal lines, indicating the imperfect joining of the coils: they are visible in the inner face and may find a counterpart in the cross-section (Figure 8). Wheel-pinched and wheel-thrown vessels instead do not show any fissures. Wheel-thrown vessels may more frequently show tears, which could rather be due to a too fast rising of the clay (Figure 11, right). 

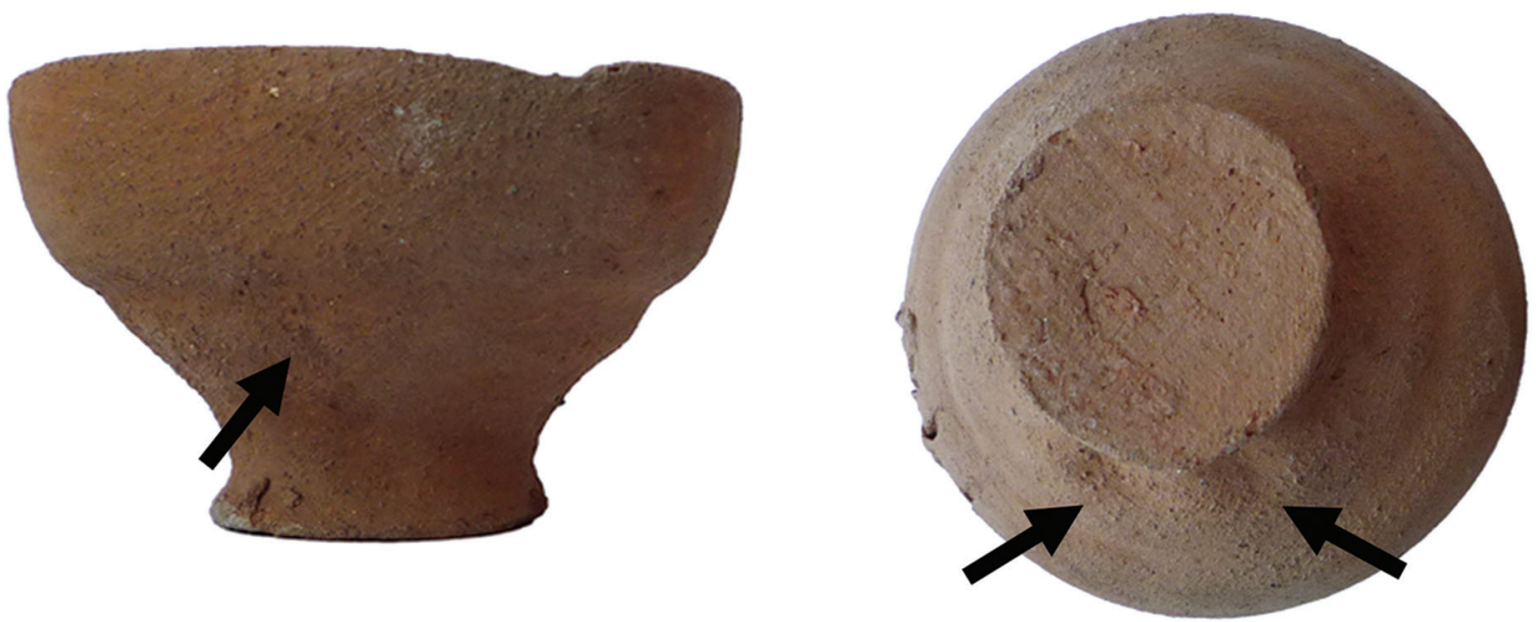

Figure 5. Handleless conical cup reproduced by V. Politakis using pinching and final shaping on the potter's wheel (wheel-pinching) with arrows indicating strong finger imprints on the outer face, near the base. Photograph by author.
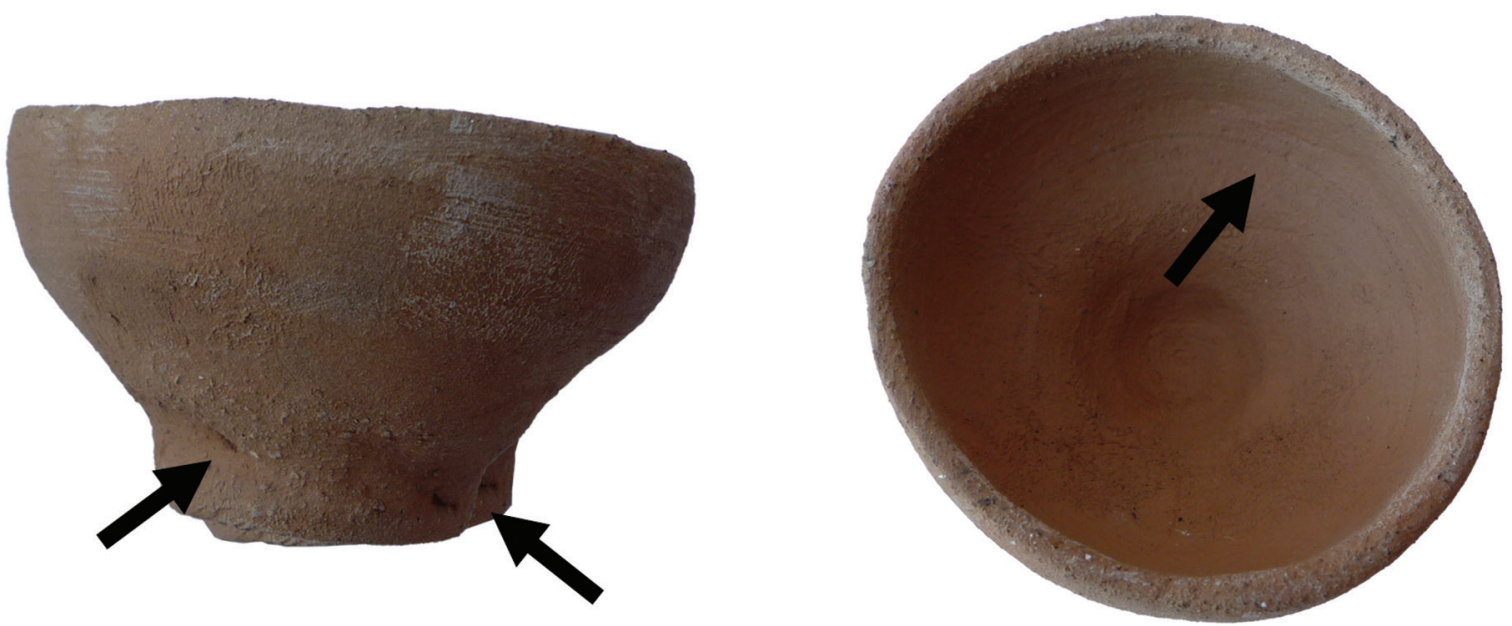

Figure 6. Handleless conical cup reproduced by V. Politakis using pinching and final shaping on the potter's wheel (wheel-pinching) with arrows indicating strong finger imprints and crevices on the outer face (left), short lines and fingerprints on the inner face (right). Photographs by author.
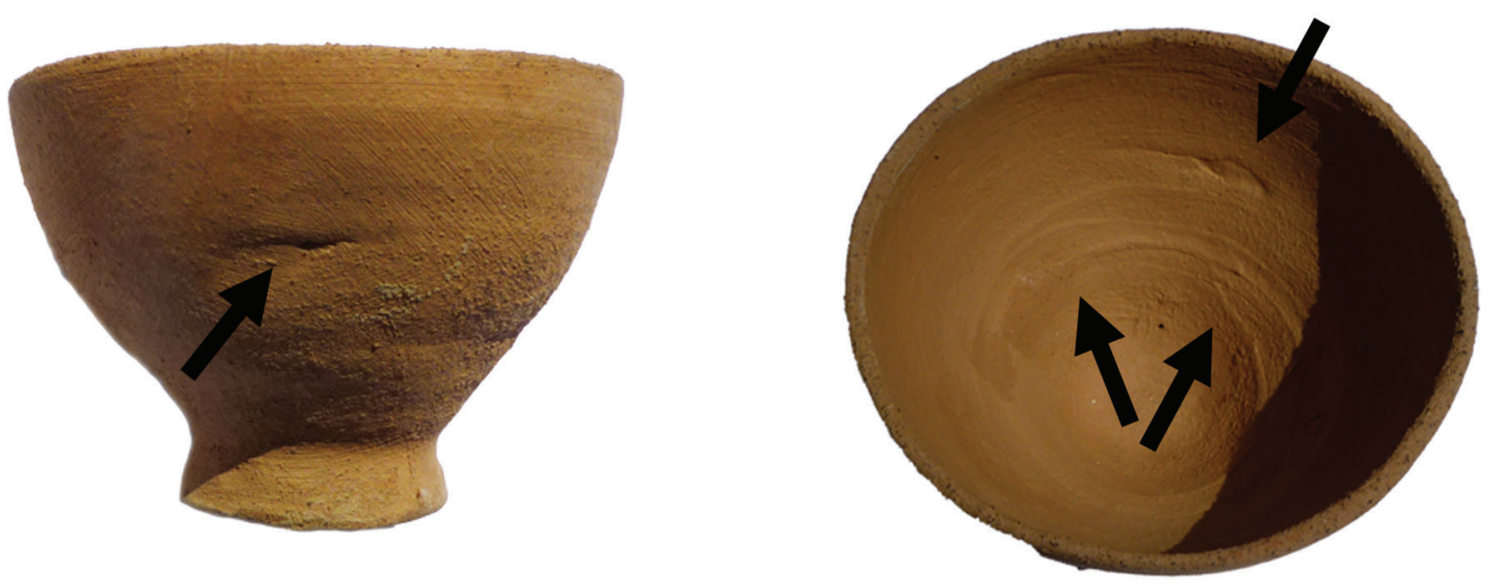

Figure 7. Handleless conical cup reproduced by V. Politakis using wheel-coiling with arrows indicating a deep horizontal fissure on the outer face (left), and curvilinear fissures and compression folds on the inner face (right). Photograph by author. 

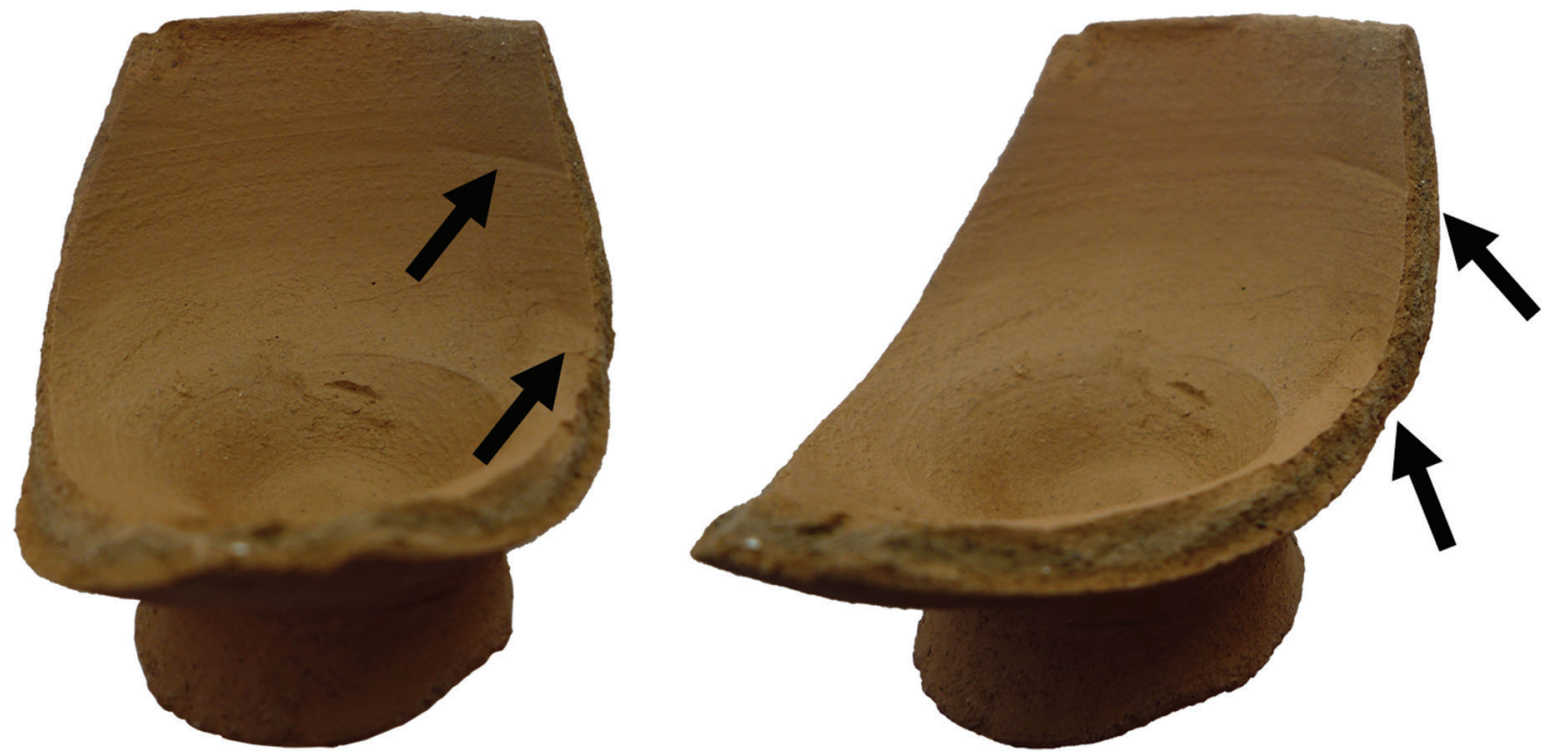

Figure 8. Handleless conical cup reproduced by V. Politakis using wheel-coiling with arrows indicating curvilinear lines on the inner face (left) and related discontinuities in the cross-section (right). Photograph by author.

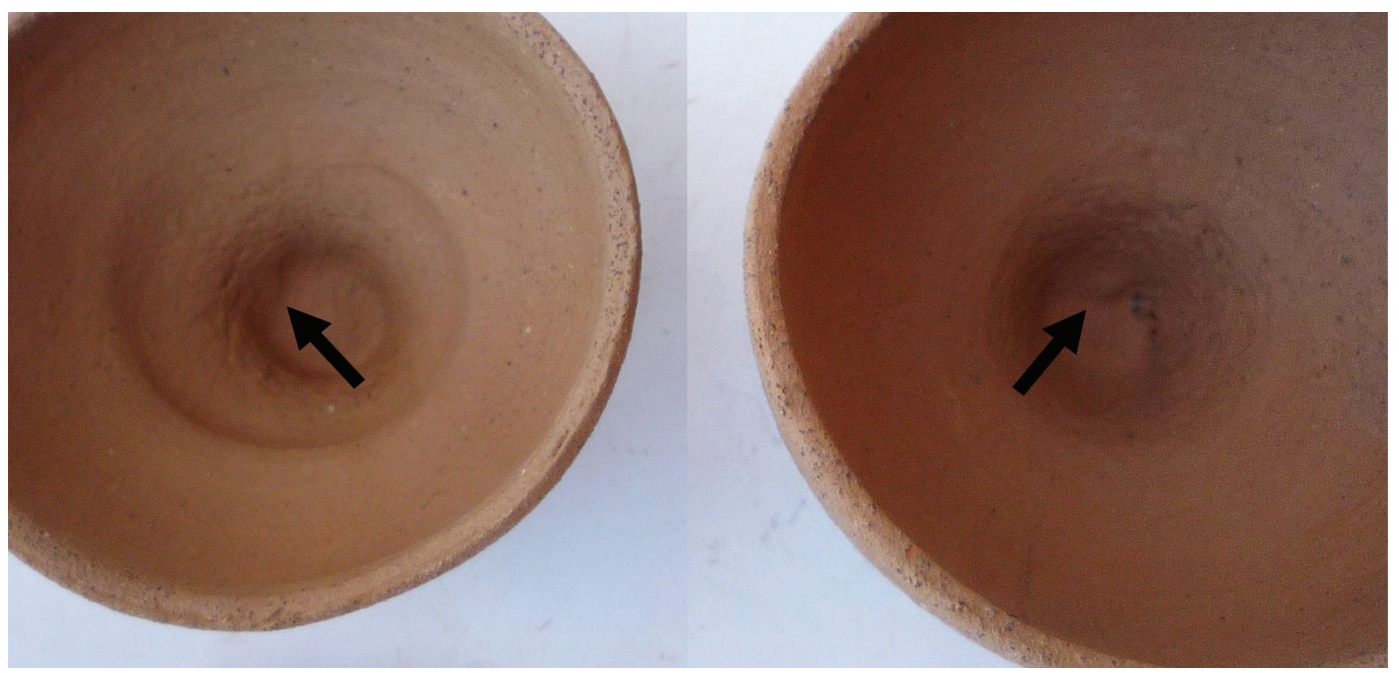

Figure 9. Handleless conical cups reproduced by V. Politakis using the throwing-off-the-hump technique with deep and narrow hollows on the base interior, with arrow indicating clay bumps. Photograph by author.

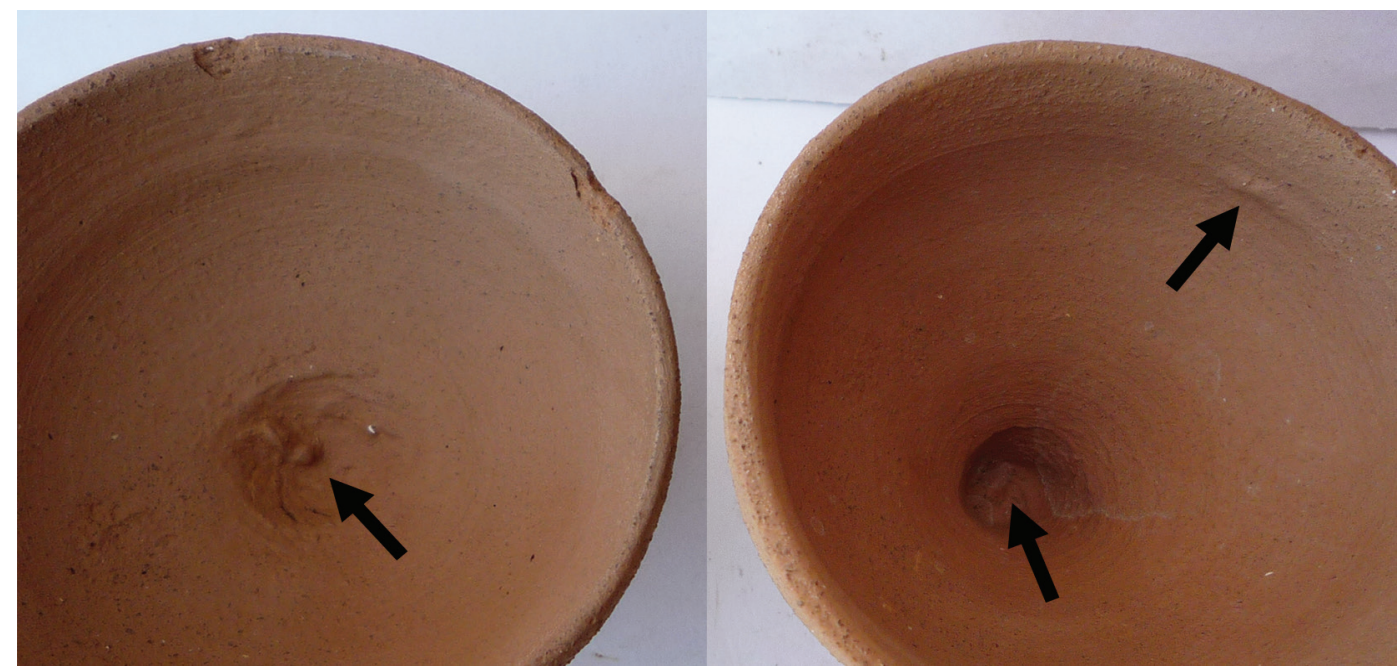

Figure 10. Handleless conical cups reproduced by V. Politakis using the throwing-off-the-hump technique with deep and narrow hollows with arrows indicating clay-barb protrusions (left) and clay bumps (right). Photographs by author. 
There are also wheel-coiled replicas that do not show specific features whatsoever, likely due to the fact that the coils have been impeccably joined. As already underlined by several authors (e.g., Van der Leeuw, 1976, p.123; Courty, Roux, 1995; Roux, 2019), the final shaping of vases can cover up any and all traces imparted during the primary forming technique.

On the analysed replicas, there are some clusters of features that seem to characterise the wheel-thrown vases, like a deep and narrow hollow on the interior of the vase, associated with clay lumps and bumps (Figure 9) and clay barb-like protrusions (Figure 10). Unlike the shallow hollow attested on some wheel-pinched and wheel-coiled experimental cups, that on the wheel-thrown ones is usually deep $(0.5 \mathrm{~cm}$.), narrow $(0.5-1.5 \mathrm{~cm})$, and of a conical section (Figures 9 and 10). It is often associated with evidence of wet clay, such as sticky fingerprints or wrinkles. The different shape of the hollow could depend on the speed of the wheel, but also on the procedure used to produce it, that is the depression of the potter's finger at the beginning of the forming and openingup process. This feature, which so far cannot be considered univocal, i.e., diagnostic of the wheel-throwing technique, has, however, also been observed by Doherty on the wheel-thrown miniatures vases from Naqada in Egypt (Doherty, 2015).

The abovementioned evidence of exceptionally wet clay, the barb-like protrusions (Figure 9 and 10) and/or sticky
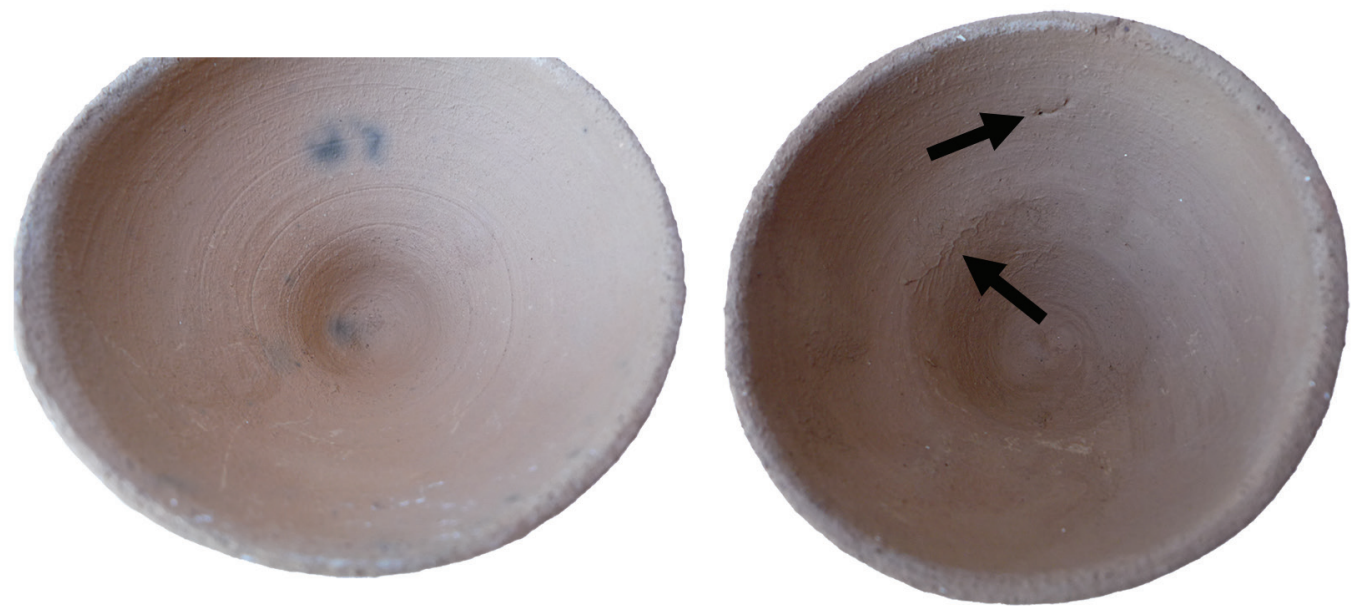

Figure 11. Handleless conical cups reproduced by V. Politakis using the throwing-off-the-hump technique with deep and narrow hollows, with arrows indicating a spiralling incised line (left), and sticky fingerprints and a tear (right). Photographs by author.
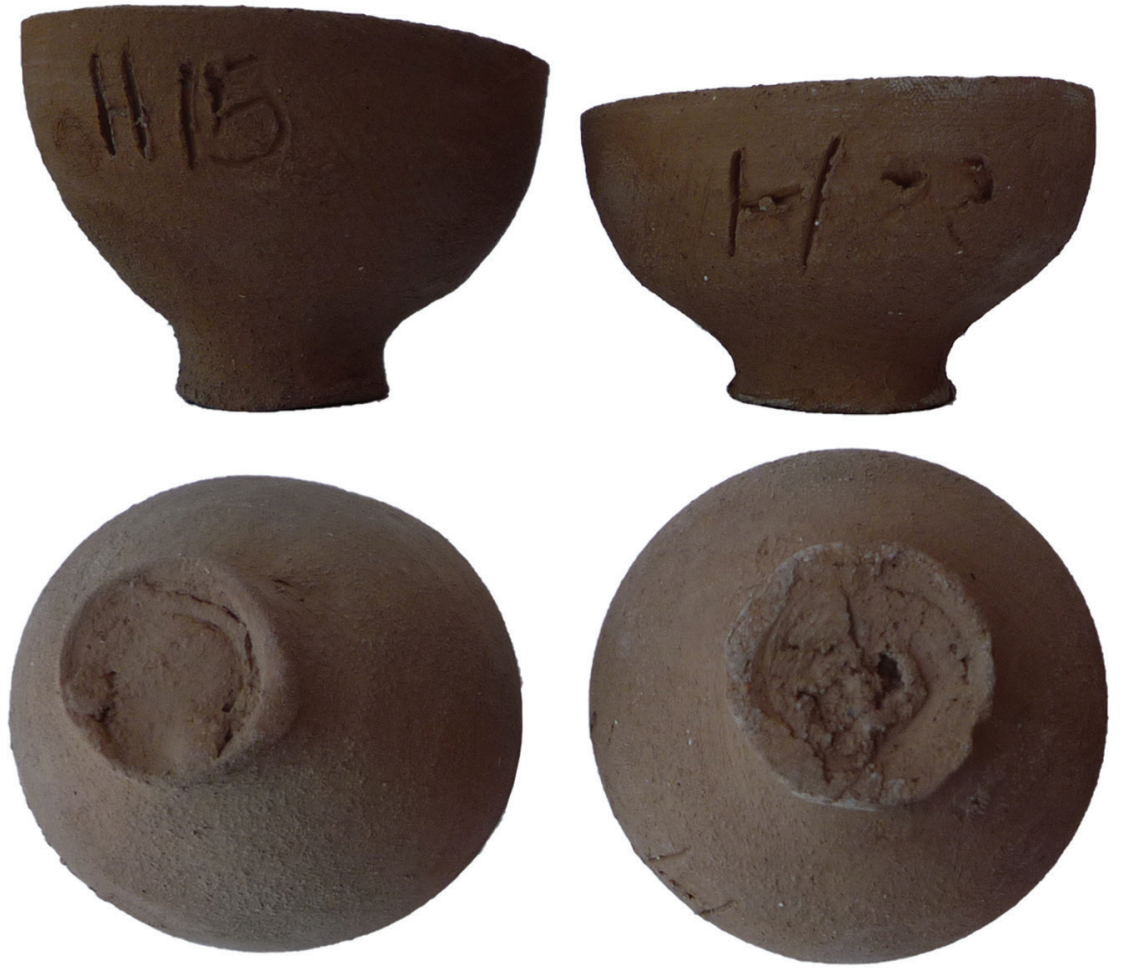

Figure 12. Handleless conical cups reproduced by V. Politakis using the throwing-off-the-hump technique and cut off the hump with a bronze needle. Photographs by author. 

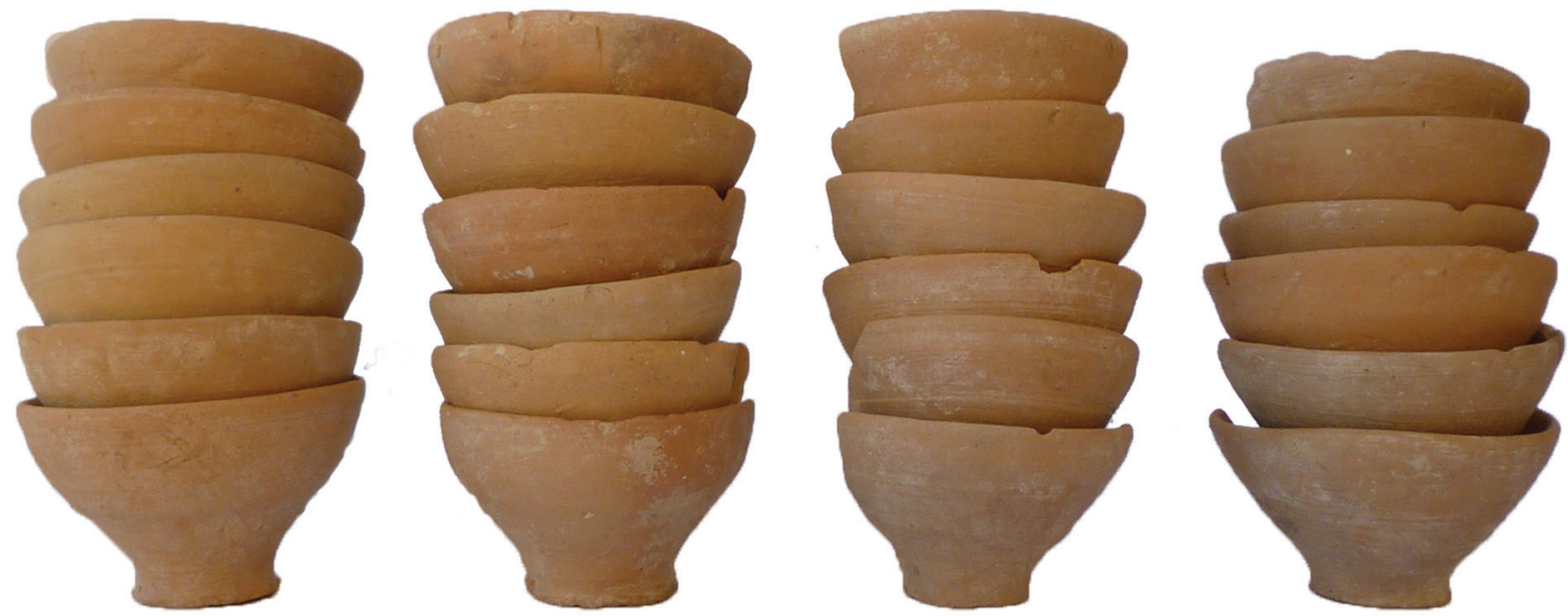

Figure 13. MM IIA Phaistian handleless conical cups from the deposit of Bastione II wall. Photograph by author.

fingerprints (Figure 11, right), could reflect the fact that the throwing-off-the-hump technique requires the clay to be kept continuously wet.

Another feature observed only on wheel-thrown replicas is the presence of an incised spiralling line going from the base to the rim (Figure 11, left), which is obtained by the finger nails of the potter or by the trailing of an impurity during the throwing of the pot. This feature is not attested on wheel-coiled replicas, where instead there are attested only linear and non-continuous incisions on the walls or near the rim.

When a needle was used to cut a cup off the hump, a very deep and semicircular incision/deformation was produced on the exterior base (Figure 12).

The experimental material has facilitated the identification of macroscopic trace combinations indicative of specific forming techniques, even if it is clear that archaeological material requires the use of more approaches.

\subsection{Analysis of the archaeological material}

The main characteristics of the two above-mentioned MM IIA ceramic deposits from the First Palace of Phaistos (Room IL bench and Bastione II wall) have been already preliminarily published in a few papers (Caloi, 2012; 2019), where I proposed that at least three specific classes of pottery and shapes seemed to be being produced through the wheelthrowing technique, whereas the rest were manufactured using the wheel-fashioning technique.

A total amount of 730 conical cups from these deposits have been analysed from a macroscopic perspective (Figure 13).

Before describing the conical cups that seem to be produced through the wheel-pinching, the wheel-coiling and the throwing-off-the hump techniques, I want to point out that in these deposits there are many specimens that cannot be attributed to a specific forming technique on the basis of the macroscopic traces left. They could have been wheelthrown, wheel-coiled or produced using other primary forming techniques (e.g., press-moulding, slab-construction, layering) combined with the potter's wheel. Accordingly, this presentation of the archaeological material does not seek to quantify the wheel-pinched, wheel-coiled and wheelthrown cups. Besides the handleless conical cups, several other types of vessels from the analysed deposits seem to have been produced using the layering technique (e.g., jars and basins), the slab construction, as well as the pressmoulding (e.g., cups and shallow bowls), in combination with the potter's wheel.

From a macroscopic point of view, the MM IIA plain handleless cups from Phaistos that seem produced through pinching and then the potter's wheel show the following characteristics: the lower part of the cup, near the base, displays many finger imprints, which can be associated with crevices (Figure 14), while the upper part, below the rim, shows a smooth, fluidified surface (Figure 14). The crevices, described by Roux (2019, pp.144-145) as tears in the paste, seem the result of a combination of shear stress and torsion. The inner face often shows a smooth surface. The rilling, whether regular (Figure 14a) or irregular (Figure 14b), is mainly visible at the external rim, rather than on the interior. On some specimens, it can be visible also on the external base.

Macroscopically, the MM IIA Phaistian plain handleless cups that seem wheel-coiled have the following characteristics: the inner and outer faces are often characterised by horizontal/curvilinear fissures (Figure 15, right), microcracks (Figures 15 and 16), and lines (Figure 16). Likewise, small, but aligned, microcracks can be visible on the inner face, sometimes associated with compression folds (Figure 15, left). All these features correspond to the incomplete joining of the coils. The latter can also be visible in the cross-section (Figure 16).

From a macroscopic point of view, the plain handleless cups that seem thrown-off-the-hump show the following characteristics: a narrow, deep and conical-in-section hollow in the inner base, often associated with clay barblike protrusions and/or bumps (Figure 17). On these same specimens, the exterior of the base shows a deep and semicircular incision, likely due to the use of a needle to cut 

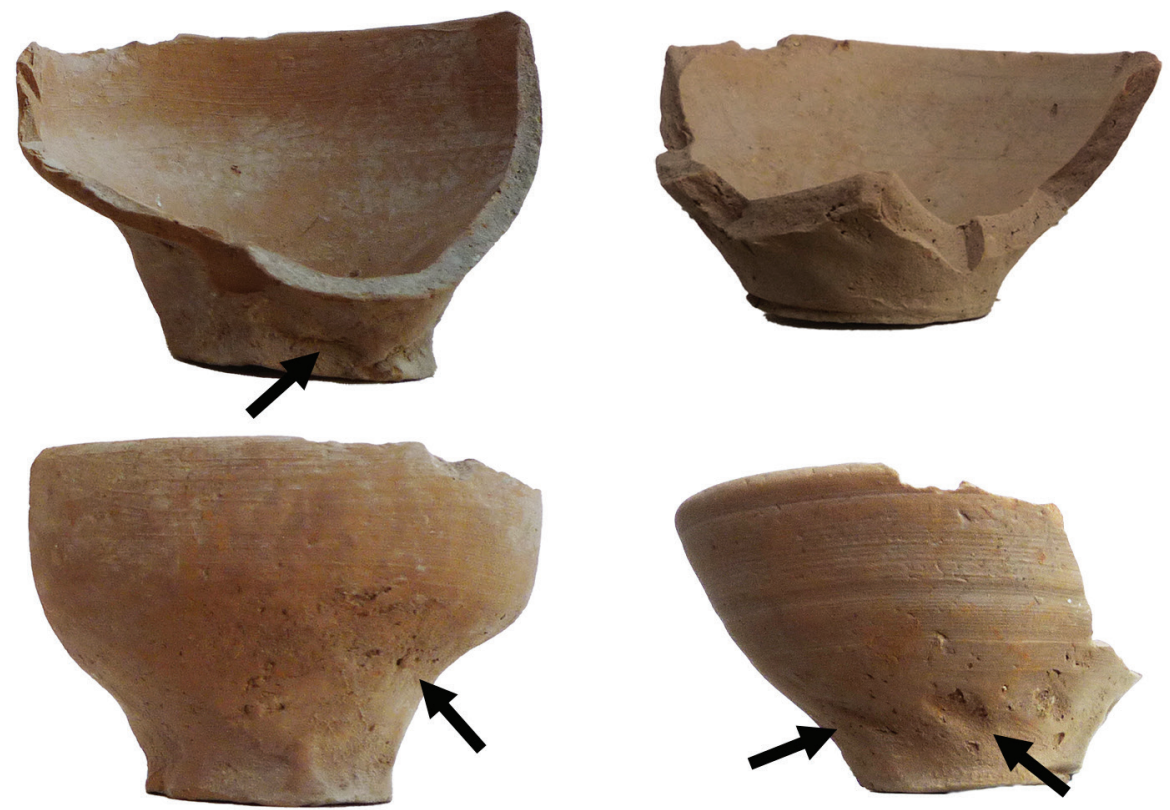

b

Figure 14. Phaistian handleless conical cups macroscopically interpreted as wheel-pinched vases with arrows indicating finger imprints and crevices on the outer faces, near the bases. Photographs by author.
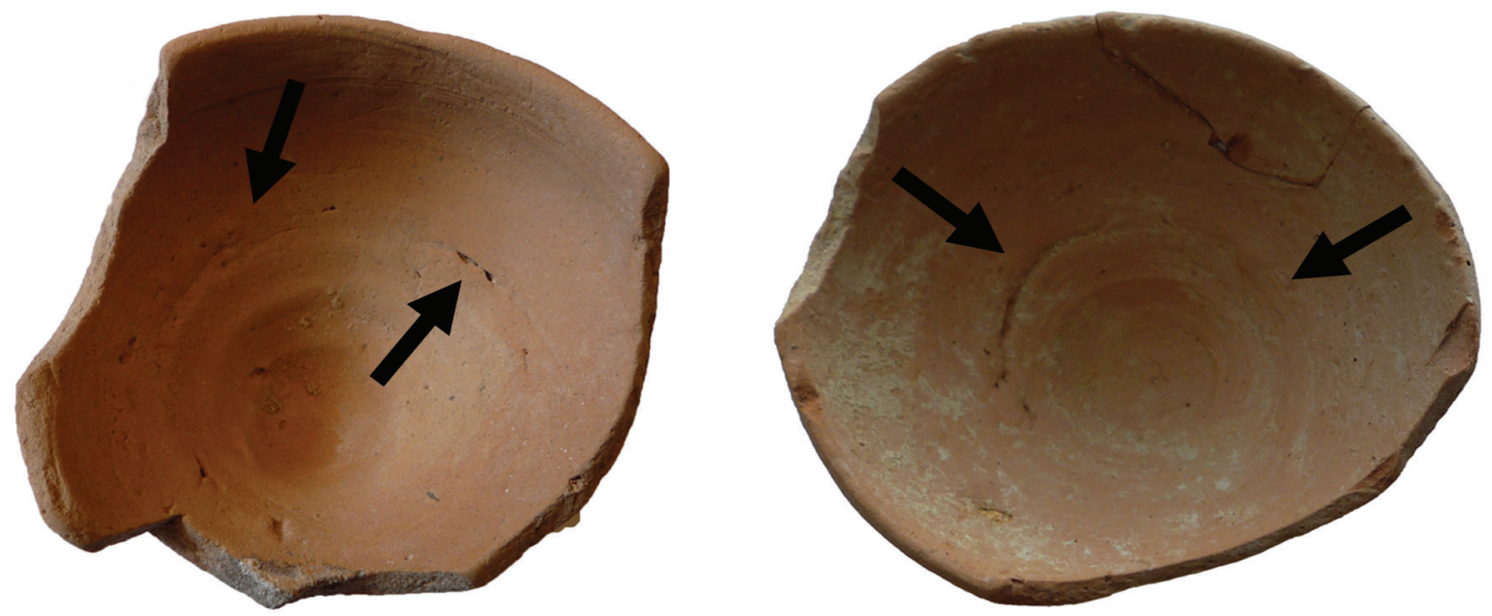

Figure 15. Phaistian handleless conical cups macroscopically interpreted as wheel-coiled vases with arrows indicating compression folds, horizontal fissures and aligned microcracks (left), and horizontal fissures (right) on the inner faces. Photographs by author.
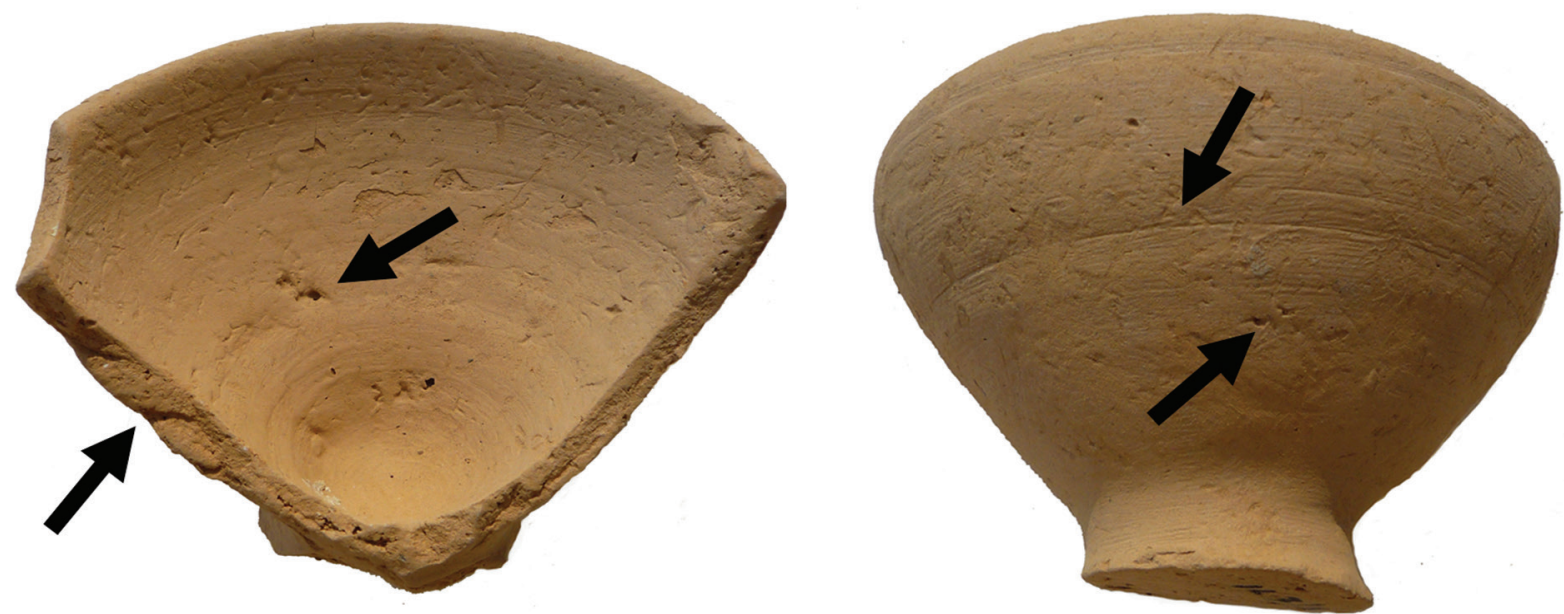

Figure 16. Phaistian handleless conical cups macroscopically interpreted as wheel-coiled vases with arrows indicating fissures and microcracks on the inner face (left), coils in cross-section (left), and horizontal lines on the outer face. Photographs by author. 

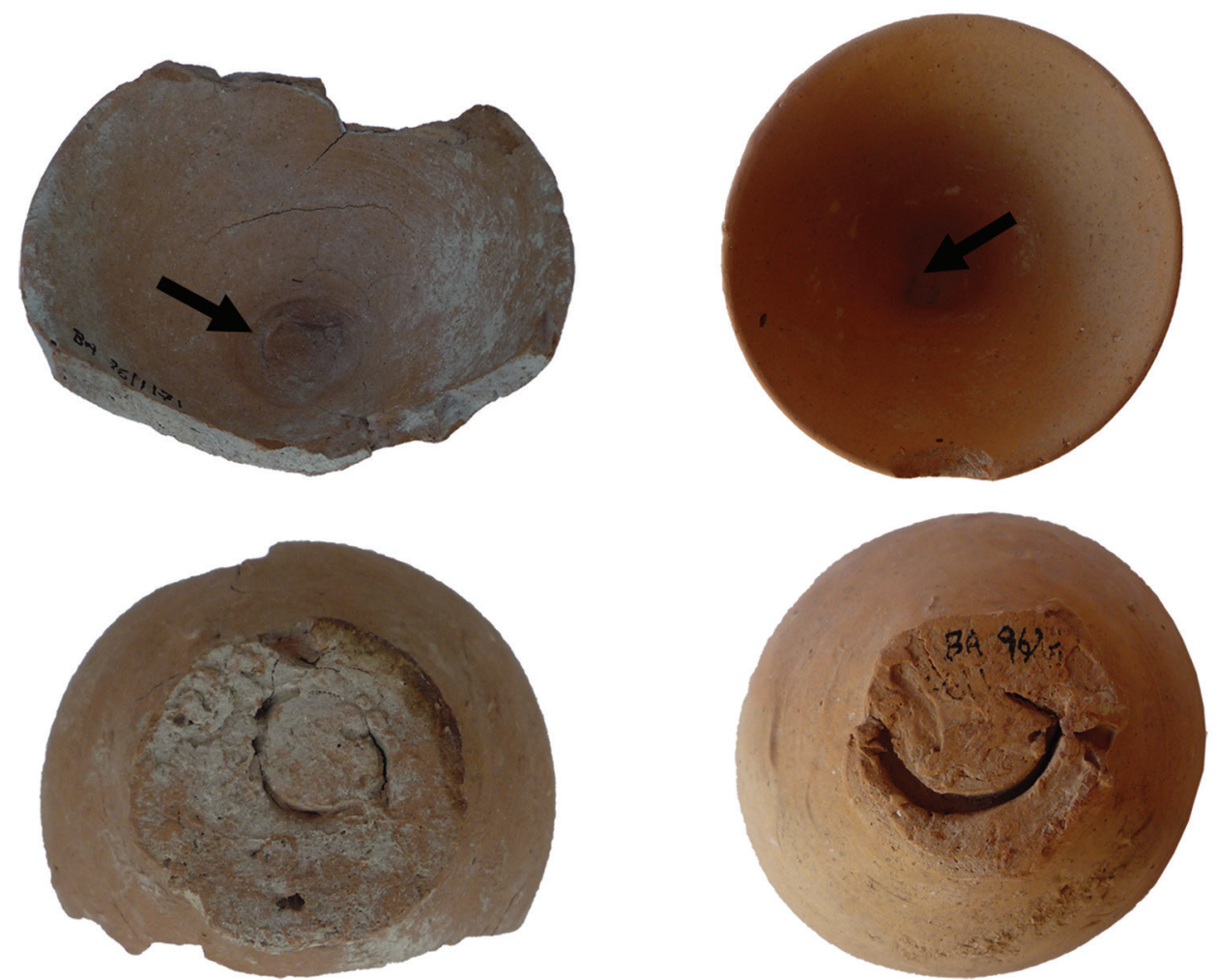

Figure 17. Phaistian handleless conical cups macroscopically interpreted as wheel-thrown vases with deep and narrow hollows with arrows indicating claybarb protrusions (left) and clay bumps (right); bases showing deep semi-circular incisions. Photographs by author.
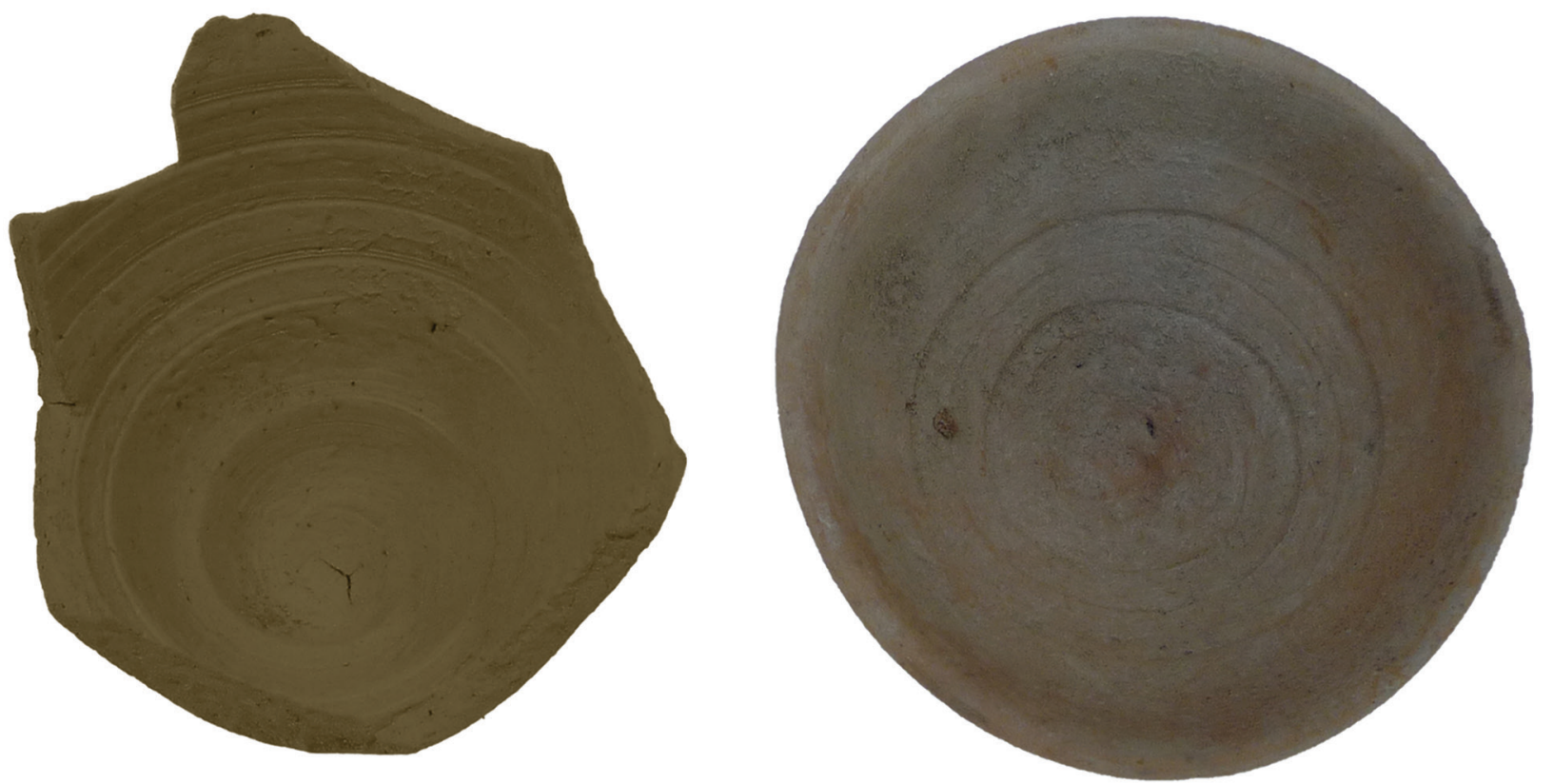

Figure 18. Phaistian handleless conical cups macroscopically interpreted as wheel-thrown vases with spiralling incised lines, sometimes associated with spiralling, even, and continuous grooves (left). Photographs by author.

the cup off the hump, as we observed on the wheel-thrown replicas (Figure 12). The inner face can be regular and smooth (Figure 17, right). It may sometimes present cracks (Figure 17, left and Figure 18, left). Sticky fingerprints may appear on the inner face (Figure 18, left), but also on the outer face.
Another feature that seems to characterise the apparently wheel-thrown cups is an incised spiralling line going from the base to the rim (Figure 18), which is often associated with even and continuous grooves.

It is interesting to observe that most of these vases show standard measurements in comparison to identified wheel- 
coiled or wheel-pinched cups. They usually have a maximum height of $4.5 \mathrm{~cm}$, a rim diameter of $7.5-8 \mathrm{~cm}$ and a very small base, ranging from 2.7 to $3.3 \mathrm{~cm}$.

\section{Results: coupling macroscopic analysis with experi- mental archaeology}

Comparing the results from experimental archaeology and macroscopic analysis, it seems that the pinching technique combined with finishing on the wheel should be the one used by Phaistian potters to produce those MM IIA cups that show both a smoothed rim and strong finger imprints near the base - something usually not present on the identified wheel-coiled cups - but no fissures and microcracks on the inner face. The near absence of fissures is likely due to the fact that pinched vases are built from a single clay ball. Since pinched-and-wheel vases show a strong difference in the care paid to the upper and to the lower part; it is likely that during the last shaping of the vase on the wheel, the attention of the potter was mainly focused on the rim.

Some Phaistian vases produced in MM IB (Caloi, 2013, Plate XXIII, Numbers 395-398, 400 and 404), the phase preceding the MM IIA one, present traces that are very similar to the ones identified on these pinched-and-wheelfinished vases. It is therefore likely that this mixed technique was in use already in MM IB to produce small drinking
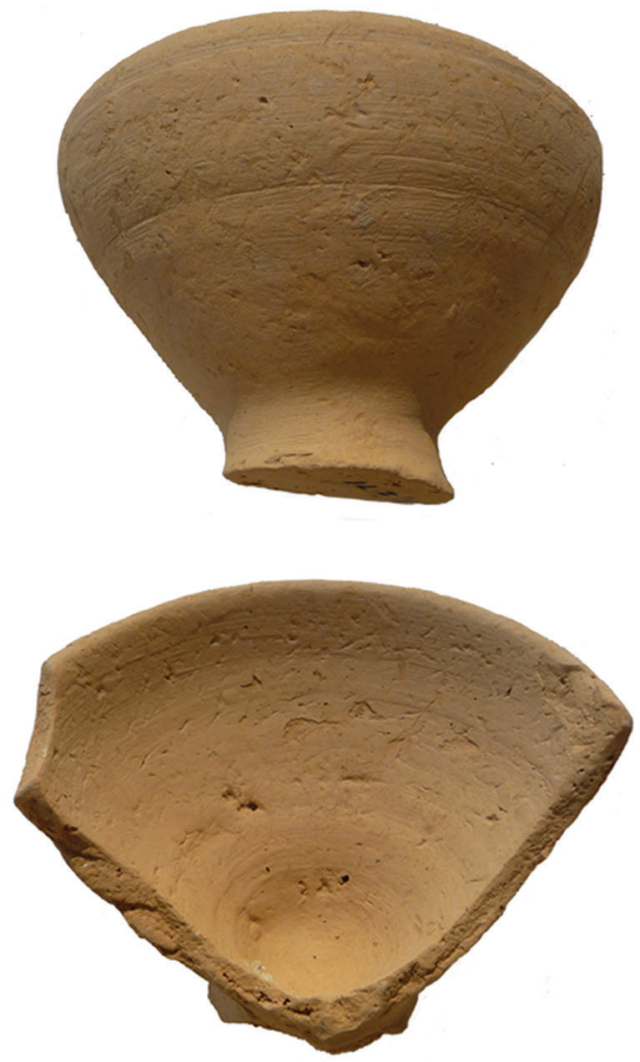

pots and was then continued in the following MM IIA. It is important to note that a progression in the shape can be seen from EM III-MM IA - when there occurred the handmade pinched conical cups (Todaro, 2017) - through to the following periods (i.e., MM IB and MM IIA), when the same cups were first produced using the pinching technique and then finished on the potter's wheel to smooth the rim.

Concerning wheel-coiled vases, the macroscopic analysis associated with the experimental archaeology has shown that the MM IIA Phaistian handleless cups that reveal horizontal/ curvilinear fissures and/or aligned microcracks should be wheel-coiled rather than wheel-thrown (Figure 19). We have already observed that these features are due to the incomplete junctions which can occur between the coils. The latter are not always visible in cross-section, but their junctions may occur both on the interior and exterior walls of the vase. The compressed folds are another feature attested on MM IIA conical cups that finds good analogies only on wheel-coiled replicas. Since handleless conical cups did not receive a final treatment of the surface, the junctions of the coils often remain visible.

The Phaistian cups that find close similarities with thrown-off-the-hump replicas are those presenting a deep and narrow hollow in the inner base, often associated with evidence of wet clay, and possibly clay bumps, clay barblike protrusions, droplets, and sticky fingerprints (Figure 20; see also Figure 17). These features cannot be considered
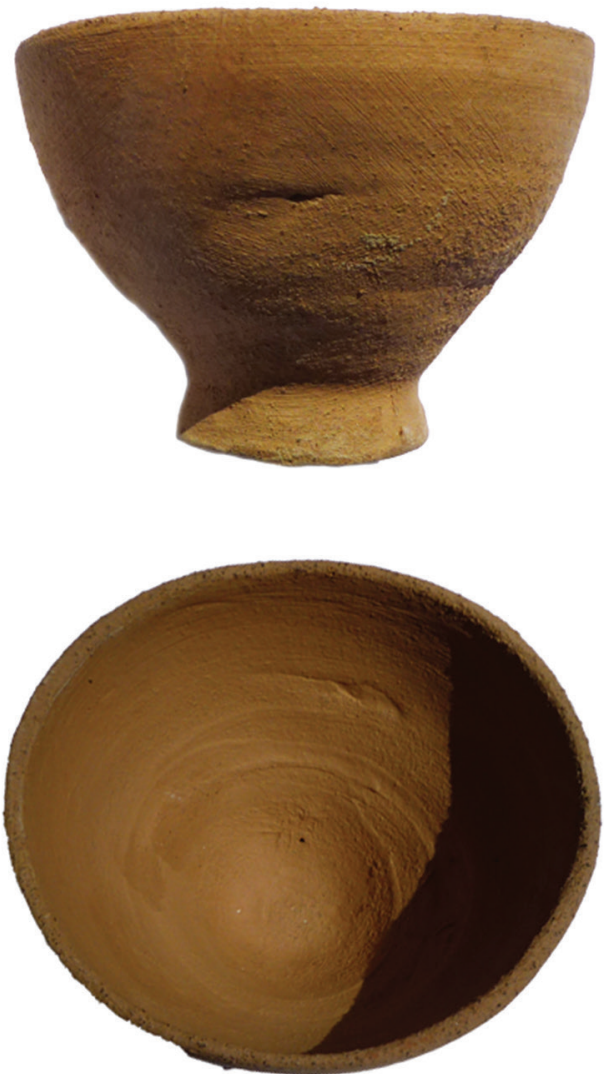

Figure 19. Comparing MM IIA Phaistian handleless conical cups macroscopically interpreted as wheel-coiled vases (left) with experimental reproductions using the wheel-coiling technique (right). Photographs by author. 

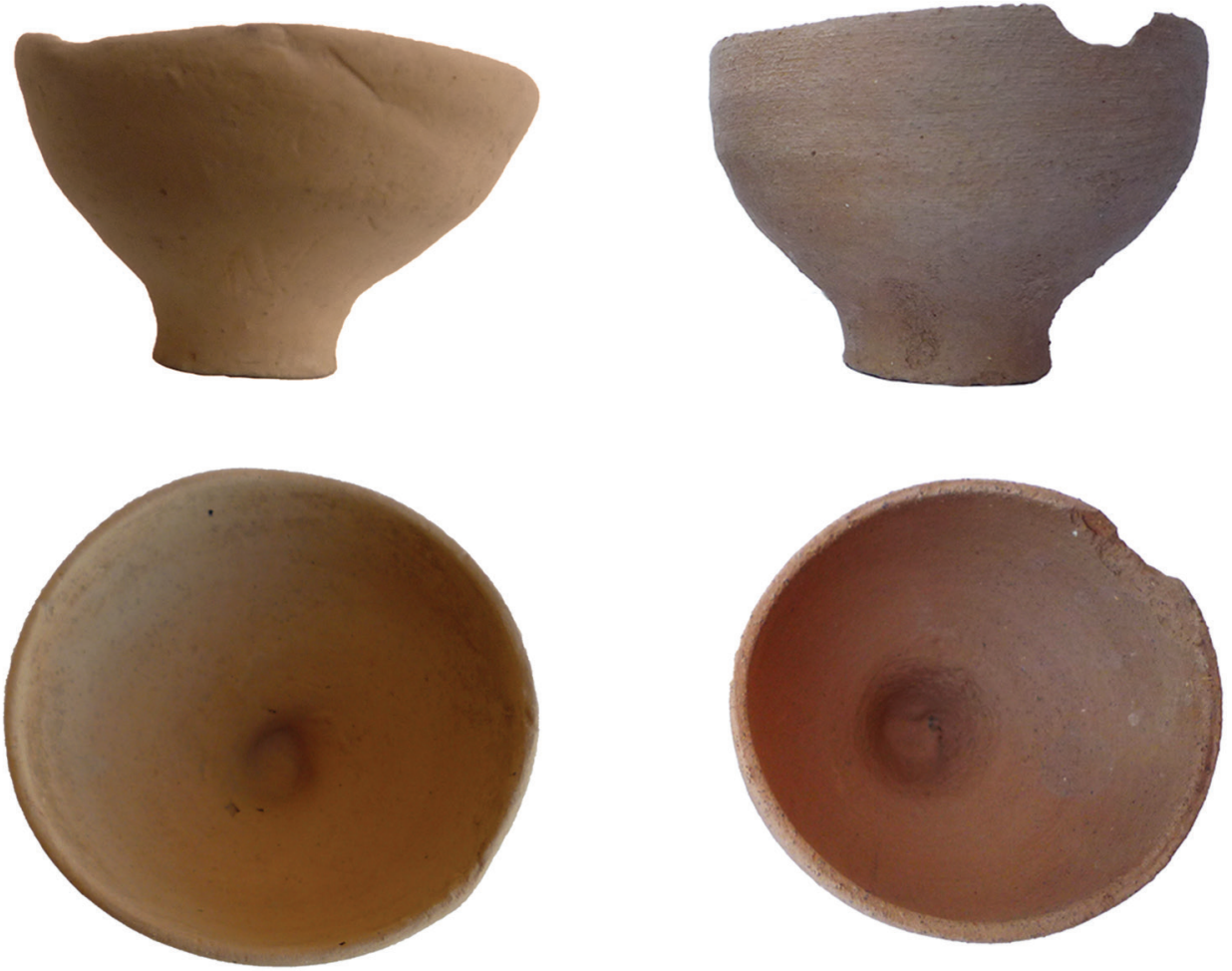

Figure 20. Comparing MM IIA Phaistian handleless conical cups macroscopically interpreted as wheel-thrown vases (left) with experimental reproductions using the throwing-off-the-hump technique (right). Photographs by author.

univocal features of the wheel-throwing technique and only future analyses will give more answers on this. It is, however, relevant to mention that Doherty $(2015$, p.89, Figure 6.23) has recently shown that in Egyptian miniature wheel-thrown cups from Naqada, the deep hole, that she called a dimple, and evidence of exceptionally wet clay, are diagnostic features of the wheel-throwing technique.

The Phaistian handleless cups showing a spiralling incision going from the base to the rim (Figure 18) find interesting similarities with the wheel-thrown replicas (Figure 11, left). Moreover, one of these Phaistian cups (Figure 18, left) shows another feature that could be attributable to the wheelthrowing technique, namely the presence of spiralling, even, and continuous grooves (see Courty, Roux, 1995; Berg, 2019).

We have already observed that some Phaistian cups (Figure 17) display a semicircular incision on the base exterior that is very similar to the ones visible on those wheel-thrown replicas, which have been cut off the hump using a needle (Figure 12).

\section{Discussion and conclusion}

The experimental archaeology I conducted with the potter Politakis has greatly improved our understanding of the different forming techniques in use in Middle Minoan Crete. The similarities found between the archaeological material from Phaistos and the replicas of three different forming techniques argues that wheel-coiling was not the only forming technique in use on Protopalatial Crete. Alongside this, it is possible that other hand-building techniques, like pinching, were used in combination with the rotary motion that the adopted potter's wheel permitted. The experimental archaeology presented here has also revealed that the archaeological material from Phaistos seems to present traces that suggest the potter's wheel was employed in its full potentiality, i.e., the wheelthrowing technique, and more specifically for throwingoff-the-hump. However, it is important to say - as already pointed out - that the experimental analysis I did has not been finished yet, hence there is no conclusive evidence for the use of the wheel-throwing technique at Protopalatial Phaistos. Further experimentation and analysis are therefore planned to investigate this. Thus, the use of X-radiography and CT scanning could be the best way forward in the future. Recent studies have indeed shown that these approaches can provide further insight on the hand-made or wheel-thrown origins of a vase (see Doherty, 2015; Kozatsas et al., 2018). The latter, associated with new analyses on the orientation of clay components in the fabric (see Thér, 2016; Thér, Toms, 2016), will probably help in defining the primary forming technique used to produce the hundreds of plain handleless cups from Phaistos that do not show any visible traces attributable to a specific technique (Figure 13).

In conclusion, this study should hopefully prompt scholars to (re)consider the appearance of wheel-made pottery in an archaeological context, bearing in mind the complexity and the dynamics in the different ways the potter's wheel can be utilised. 


\section{Acknowledgements}

My warmest thanks go to Filippo Carinci for giving me the opportunity to work at Phaistos and to study the Protopalatial pottery of the site. Special thanks to Simona Todaro for discussing many aspects of this paper with me and to Mattia Zantedeschi for helping me with the pictures. I am thankful to Don Evely for improving the English of my paper and to the two anonymous reviewers for their useful suggestions.

\section{References}

BALDACCI, G., 2017. L'edificio protopalaziale dell'Acropoli Mediana di Festòs (Vani $\mathrm{CV}-\mathrm{CVII}$ ). Venezia: Edizioni $\mathrm{Ca}^{\prime}$ Foscari.

BALDACCI, G., forthcoming. Haghia Triada. I livelli protopalaziali dall'insediamento.

BERG, I., 2009. X-Radiography of Knossian Bronze Age vessels: assessing our knowledge of primary forming techniques. Annual of the British School at Athens, 104, 137-173.

BERG, I. 2011. What's in a forming technique? An investigation into wheel-throwing and wheel-coiling in Bronze Age Crete. The Old Potter's Almanack 16(2), 9-12.

BERG, I., 2019. The potter's wheel. In: The Encyclopedia of Global Archaeology. Cham: Springer, pp. 1-13.

BETANCOURT, P.P., et al., 1979. Vasiliki Ware. An Early Bronze Age Pottery Style in Crete. Studies in Mediterranean Archaeology, 56. Göteborg: P. Åström.

CALOI, I., 2009. For a new ceramic sequence of Protopalatial Phaistos (MM IB-MM IIA) and some observations on Barbotine Ware. Creta Antica, 10(2), 373-440.

CALOI, I., 2011. Le innovazioni tecnologiche nella Messarà: dal wheelfashioning al wheel-throwing. In: F. Carinci, N. Cucuzza, P. Militello, and O. Palio, eds. Kretes Minoidos. Tradizione e identità minoica tra produzione artigianale, pratiche cerimoniali e memoria del passato. Padova: Bottega d'Erasmo, pp. 87-102.

CALOI, I., 2012. Memory of a feasting event in the First Palace of Phaistos: preliminary observations on the bench deposit of Room IL. Creta Antica, $13,41-59$.

CALOI, I., 2013. Festòs Protopalaziale. Il quartiere ad Ovest del Piazzale I. Strutture e ritrovamenti delle terrazze mediana e superiore. Venezia: Edizioni $\mathrm{Ca}$ ' Foscari.

CALOI, I., 2016. La Creta Minoica del Medio Bronzo (XXI-XVII sec. a.C.): tradizione e innovazione nella tecnologia ceramica. In: N. Cucuzza, B.M. Giannattasio, and S. Pallecchi, eds. Archeologia delle produzioni ceramiche nel mondo antico. Spazi, prodotti, strumenti e tecniche. Genova: Quaderni di Archeologia, pp. 21-42.

CALOI, I., 2019. Breaking with tradition? The adoption of the wheelthrowing technique at Protopalatial Phaistos: Combining macroscopic analysis, experimental archaeology and contextual information. Annuario della Scuola Archeologica di Atene e delle Missioni Italiane in Oriente, 97, 9-25.

CHOLEVA, M., 2012. The First Wheelmade pottery at Lerna: wheelthrown or wheel-fashioned? Hesperia, 81, 343-381.

COURTY, M.-A, and ROUX, V., 1995. Identification of wheel-throwing on the basis of ceramic surface features and microfabrics. Journal of Archaeological Science, 22, 17-50.

DAY, P.M, RELAKI, M., and FABER, E.W., 2006. Pottery Making and Social Reproduction in the Bronze Age Mesara. In: M. Wiener, J.L. Warner, J. Polonsky, and E. Hayes, eds. Pottery and Society: The Impact of Recent Studies in Minoan Pottery. Boston: Archaeological Institute of America, pp. 22-72.

DOHERTY, S.K., 2015. The origins and use of the potter's wheel in Ancient Egypt. Oxford: Archaeopress.

EVELY, R.D.G., 1988. The Potters' Wheel in Minoan Crete. Annual of the British School at Athens, 83, 83-126.

EVELY, R.D.G., 2000. Minoan Crafts: Tools and Techniques. An Introduction. Studies in Mediterranean Archaeology, 92(2), Jonsered: Paul Åström.
EVELY, R.D.G., and MORRISON, J.E., 2010. The Minoan Potter's Wheel: A Study in Experimental Archaeology, In: P. Matthiae, F. Pinnock, L. Nigro, and N. Marchetti, eds. Proceedings of the $6^{\text {th }}$ International Congress on the Archeology of the Ancient Near East, vol. I. Wiesbaden: Harrassowitz Verlag, pp. 283-288.

FIANDRA, E., 1973. Skoutelia MM a Festòs. In: Pepragmena tou $\Gamma$ Diethnous Kritologikou Synedriou, Rethymno 1971. Athenai: Ypourgeio Politismou kai Epistemon, pp. 85-91.

JEFFRA, C., 2011. The archaeological study of innovation: An experimental approach to the pottery wheel in Bronze Age Crete and Cyprus. Unpublished thesis $(\mathrm{PhD})$, University of Exeter.

JEFFRA, C., 2013. A reexamination of early wheel potting in Crete. Annual of the British School at Athens, 108, 31-49.

HAMPE, R., and WINTER, A. 1962. Bei Töpfern und Töpferinnen in Kreta Messsenien und Zypern, Mainz: Verlag des Römisch-Germanischen Zentralmuseums.

KNAPPETT, C., 1999. Tradition and innovation in pottery forming technology: wheel-throwing at Middle Minoan Knossòs. Annual of the British School at Athens, 94, 101-129.

KNAPPETT, C., 2004. Technological innovation and social diversity at Middle Minoan Knossos. In: G. Cadogan, E. Hatzaki, and A. Vasilakis, eds. Knossos: Palace, City, State. British School at Athens Studies, 12. Athens: British School at Athens, pp. 257-265.

KNAPPETT, C., 2016. Resisting innovation? Learning, cultural evolution and the potter's wheel in the Mediterranean Bronze Age. In: L. Mendoza Straffon, ed. Cultural Phylogenetics. Concepts and Applications in Archaeology. Heidelberg: Springer, pp. 97-111.

KOZATSAS, J., KOTSAKIS, K., SAGRIS, D., and DAVID, K., 2018. Inside out: assessing pottery forming techniques with micro-CT scanning. An example from Middle Neolithic Thessaly. Journal of Archaeological Science, 100, 102-119.

LEVI, D., 1976. Festòs e la Civiltà Minoica, vol. I. Incunabula Graeca, 60. Roma: Edizioni dell'Ateneo.

LEVI, D., and CARINCI, F., 1988. Festòs e la Civiltà Minoica, vol. II. Incunabula Graeca, 77. Roma: Edizioni dell'Ateneo.

MACDONALD, C.F., and KNAPPETT, C. 2007. Knossos: Protopalatial Deposits in Early Magazine A and the South-West Houses. British School at Athens Supplement, 41. London: The British School at Athens.

MAGILlIVRAY, J.A., 1998. Knossos: Pottery Groups of the Old Palace Period. British School at Athens Studies, 5. London: The British School at Athens.

MAGILLIVRAY, J.A., 2007. Protopalatial (MM IB-MM IIIA): Early Chamber beneath the West Court, Royal Pottery Stores, the Trial KV, and the West and South Polychrome Deposits Groups. In: N. Momigliano, ed. Knossos Pottery Handbook: Neolithic and Bronze Age (Minoan). British School at Athens Studies, 14. London: The British School at Athens, pp. 105-149.

MENTESANA, R. et al., 2016. Looking for the invisible: landscape change and ceramic manufacture during the Final Neolithic-Early Bronze Age at Phaistos. In : M. Ghilardi, ed. Géoarchéologie des iles de Méditérranée. Paris: CNR Éditions, pp. 299-310.

MORRISON, J.E., and PARK, D.P., 2008. Throwing Small Vessels in the LM IB Mochlos Potter's Pit. Kentro, 10, 6-10.

O'SULLIVAN, A., et al., 2014. Experimental archaeology: making; understanding; story-telling. In: B. Kelly, N. Roycroft, and M. Stanley, eds. Fragments of Lives Past: archaeological objects from Irish road schemes. Dublin: National Roads Authority, pp. 115-126.

OUTRAM, A.K., ed., 2008. Experimental archaeology. World Archaeology, 40(1), Routledge.

POURSAT, J.-C., and KNAPPETT, C., 2005. Fouilles Exécutées à Malia: Le Quartier Mu IV. La Poterie du Minoen Moyen II : Production et Utilisation. Études Crétoises, 33. Athènes: École Française d'Athènes.

POWELL, C., 1995. The nature and use of ancient Egyptian potter's wheels. In: B. Kemp, ed. Amarna reports. Occasional Publications, 6, pp. 309-335.

PUGLISI, D., 2018. Ruote da vasaio TM I da Haghia Triada: aspetti tecnologici e valenze culturali. In: G. Baldacci, and I. Caloi, eds. Rhadamanthys. Studies in Minoan archaeology in honour of Filippo Carinci on the occasion of his $70^{\text {th }}$ birthday. Oxford: BAR Publishing, pp. 167-178.

ROUX, V., 2019. Ceramics and Society. A technological approach to archaeological assemblages. Switzerland: Springer Nature. 
ROUX, V., and COURTY, M.-A., 1998. Identification of wheel-fashioning methods: technological analysis of $4^{\text {th }}-3^{\text {rd }}$ millennium $B C$ Oriental ceramics. Journal of Archaeological Science, 25, 747-763.

ROUX, V., and JEFFRA, C., 2015. The spreading of the potter's wheel in the Ancient Mediterranean: a context dependent phenomenon. In: W. Gauss, G. Klebinder-Gauss, and C. von Ruden, eds. The Transmission of technological knowledge in the production of Ancient Mediterranean pottery. Wien: Verlag der Österreichischen Akademie der Wissenschaften, pp. 165-182.

RICE, P.M., 1987. Pottery Analysis: A Source Book. Chicago: University of Chicago Press.

SPEZIALE, A., 1999. Accorgimenti funzionali ed espedienti tecnici nella ceramica MM di Festòs. In: V. la Rosa, D. Palermo, and L. Vagnetti, eds. Epì pónton plazómeni. Simposio italiano di studi egei dedicato a L. Bernabò Brea e G. Pugliese Carratelli. Roma, pp. 109-114.

THÉR, R., 2016. Identification of pottery-forming techniques using quantitative analysis of the orientation of inclusions and voids in thin sections. Archaeometry, 58, 222-238.

THÉR, R., and TOMS, P., 2016. Quantification of the orientation and alignment of a plastic components of a ceramic body as a method for distinguishing among various means of using a rotational device in pottery forming. Journal of Archaeological Science, 9, 33-43.

TODARO, S., 2009. Pottery production in the Prepalatial Mesara: the Artisans' quarter to the West of the palace at Phaistos. Creta Antica, $10(2), 333-352$.
TODARO, S., 2016. Shaping tools and finished products from a pottery production area at Phaistos. A combined approach to the study of forming techniques in Early and Middle Minoan Crete. Creta Antica, 17, 273-325.

TODARO, S., 2017. Forming techniques and cultural identity in Early and Middle Minoan Crete: multi-layered vessels from a pottery production area at Phaistos. Annuario della Scuola Archeologica di Atene e delle Missioni Italiane in Oriente, 95, 127-141.

TODARO, S., 2019. "Riscavare lo scavato". Building up the stratigraphy of Prepalatial Phaistos with legacy data. Catania: Universitá di Catania.

VAN DE MOORTEL, A., 2006. Middle Minoan IA and Protopalatial Pottery. In: J. Shaw, and M.C. Shaw, eds. Kommos V. The Monumental Buildings at Kommos. Princeton: Princeton University Press, pp. 264-377.

VAN DER LEEUW, S.E., 1976. Studies in the technology of ancient pottery. Amsterdam, University of Amsterdam.

XANTHOUDIDES, S., 1927. Some Minoan Potter's-Wheel Discs. In S. Casson, ed. Essays in Aegean Archaeology presented to Sir Arthur Evans in honour of his $75^{\text {th }}$ birthday. Oxford: Oxford University Press, pp. 111-128.

WIENER, M.H., 2011. Conical Cups: From Mystery to History. In: W. Gauss, M. Lindblom, R.A.K. Smith, and J.C. Wright, eds. Our Cups Are Full: Pottery and Society in the Aegean Bronze Age. Oxford: Archaeopress, pp. 355-368. 